\title{
Uses of tree saps in northern and eastern parts of Europe
}

\author{
Ingvar Svanberg ${ }^{1}$, Renata Sõukand ${ }^{2 *}$, Łukasz Łuczaj ${ }^{3}$, Raivo Kalle ${ }^{4}$, Olga Zyryanova ${ }^{5}$, Andrea Dénes ${ }^{6}$, Nóra Papp ${ }^{7}$, \\ Aneli Nedelcheva ${ }^{8}$, Daiva Šeškauskaitè ${ }^{9}$ I Iwona Kołodziejska-Degórska ${ }^{10,11}$, Valeria Kolosova ${ }^{12}$ \\ ${ }^{1}$ Uppsala Centre for Russian and Eurasian Studies, Uppsala University, Box 514, 75120 Uppsala, Sweden \\ ${ }^{2}$ Estonian Literary Museum, Vanemuise 42, 51003 Tartu, Estonia \\ ${ }^{3}$ Department of Botany and Biotechnology of Economic Plants, University of Rzeszów, Werynia 502, 36-100 Kolbuszowa, Poland \\ ${ }^{4}$ Institute of Veterinary Medicine and Animal Sciences, Estonian University of Life Sciences, Kreutzwaldi 62, 51014 Tartu, Estonia \\ ${ }^{5}$ V. N. Sukachev Institute of Forest, Russian Academy of Sciences, Academgorodok 50, 660036 Krasnoyarsk, Russia \\ ${ }^{6}$ Natural History Department, Janus Pannonius Museum, Box 158, 7601 Pécs, Hungary \\ ${ }^{7}$ Department of Pharmacognosy, University of Pécs, Rókus 2, 7624 Pécs, Hungary \\ ${ }^{8}$ Department of Botany, Sofia University "St. Kliment Ohridski", Dragan Tzankov 8, 1164 Sofia, Bulgaria \\ ${ }^{9}$ Kaunas Forestry and Environmental Engineering University of Applied Sciences, Liepu 1, Girionys, LT 53101 Kaunas, Lithuania \\ ${ }^{10}$ Warsaw University Botanic Garden, Aleje Ujazdowskie 4, 00-478 Warsaw, Poland \\ ${ }^{11}$ Institute for Interdisciplinary Research “Artes Liberales", University of Warsaw, Nowy Świat 69, 00-046 Warsaw, Poland \\ ${ }^{12}$ Institute for Linguistic Studies, Russian Academy of Sciences, Tuchkov pereulok 9, 199053 Saint-Petersburg, Russia
}

\section{Abstract}

In this article we review the use of tree saps in northern and eastern Europe. Published accounts by travellers, ethnologists and ethnobotanists were searched for historical and contemporary details. Field observations made by the authors have also been used. The presented data shows that the use of tree sap has occurred in most north and eastern European countries. It can be assumed that tree saps were most used where there were extensive stands of birch or maple trees, as these two genera generally produce the largest amount of sap. The taxa most commonly used have been Betula pendula, B. pubescens, and Acer platanoides, but scattered data on the use of several other taxa are presented.

Tree sap was used as a fresh drink, but also as an ingredient in food and beverages. It was also fermented to make light alcoholic products like ale and wine. Other folk uses of tree saps vary from supplementary nutrition in the form of sugar, minerals and vitamins, to cosmetic applications for skin and hair and folk medicinal use.

Russia, Ukraine, Belarus, Estonia, Latvia and Lithuania are the only countries where the gathering and use of sap (mainly birch sap) has remained an important activity until recently, due to the existence of large birch forests, low population density and the incorporation of sap into the former Soviet economic system.

It is evident that gathering sap from birch and other trees was more widespread in earlier times. There are records indicating extensive use of tree saps from Scandinavia, Poland, Slovakia and Romania, but it is primarily of a historical character. The extraction of tree sap in these countries is nowadays viewed as a curiosity carried out only by a few individuals. However, tree saps have been regaining popularity in urban settings through niche trading.

Keywords: sap collection, fermented beverages, non-timber forest products, ethnobotany, forestry, food culture

\section{Introduction}

Tree sap has traditionally been a source of nutrients in the spring in the boreal and hemiboreal regions of the northern hemisphere. The famous Arab traveller Ahmad ibn Fadlān

\footnotetext{
* Corresponding author. Email: renata@folklore.ee

This is an Open Access digital version of the article distributed under the terms of the Creative Commons Attribution 3.0 License (creativecommons.org/licenses/by/3.0/), which permits redistribution, commercial and non-commercial, provided that the article is properly cited.
}

observed as early as 921 that the Turkish-speaking Bolgars along the Volga River used fermented birch sap. The German scholar Conrad of Megenberg (14th century) mentions its use as a refreshing drink. The Persian geographer Rashīd al-Dīn also describes in his "Jāmi" al-tawārīkh" from the early 14th century that the Uriankhai people in Siberia cut birch trunks and gathered the sap, which was drunk instead of water. Italian botanist Pietro Andrea Mattioli praised its medicinal properties in 1561. According to him it could be used for treating stones in the kidney and the bladder, but also to cure ulcers [1-5]. In his thesis "Disputatio physico-medica votiva" written in 1631 in Tartu, the physician Johannes Raicus praised birch sap and suggested its use in medicine, comparing its healing properties with those of mineral water [6]. 
It was common practice to tap the liquid from various kinds of trees to obtain a beverage in times of want. The sweet taste of the sap was a welcome change after the long winter in social contexts where sugar was rare. A deficiency of food in early spring was customary in northern Europe until the end of the 19th century, and in eastern Europe until the 1960s. Tree sap has been used for several purposes other than just a source of sugar. Actually, many different products are made out of it, such as fermented beverages, beer, wine, and syrup. Swedish ethnologist Gösta Berg even suggested that tree sap was also probably the most used and one of the most effective medicines against scurvy in earlier times [1].

Internationally, the best known product made of tree sap is the Canadian maple syrup that led to the maple leaf becoming the symbol of the country. Sap from the sugar maple tree (Acer saccharum Marshall) and some related species was being processed among indigenous peoples of North America long before Europeans arrived on the continent [7-9]. In northern and eastern Europe maple sap is less frequently gathered, although it is utilised in some regions. Nevertheless, maple sap is valued for its sweet taste, as it contains more sugar than birch sap. Other tree taxa have also been utilised in eastern and northern Europe as sources of sap [1,10].

Birch sap has been considered one of the most profitable non-timber forest products $[11,12]$. Experiments conducted in Estonia in the 1970s showed that the profit gained from the sap was six times the profit gained from timber [13]. A birch tree can produce $36 \mathrm{l}$ of sap in nine days [14]. In Alaska over 1000 gallons (3785 1) of birch syrup are made every year. The quality of the product is regulated by Alaska Birch Syrup-makers Association and although the production of birch syrup is five times more costly than maple syrup, it has its own market due to its specific taste [15].

There has been little scientific investigation and current research into the technology of production of tree sap in Europe, and only a few of these studies have been published in English, mainly concerning Finland [16-27]. The content of sugar in the European species of birches can reach $0.8 \%$ of their weight [25]. The only part of Eurasia where birch sap was industrially gathered was in the Soviet Union. Hence, most of the research on technology, productivity and resources has been published in Russian. In the former Soviet Union, research on birch sap indicates that it can be used against anaemia, cancer, tuberculosis, kidney and liver stones, gout, arthritis, rheumatism, cold and skin diseases. It also has diuretic properties, can be used as worm powder and prevents tooth troubles [28-33]. "Biomos", a medicine, based on birch sap, has been found to heal wounds and burns and work as an antiphlogistic and antisclerotic substance [34]. In veterinary medicine birch sap cures some cattle diseases and increases milk production [35], while in bee farming it is used as extra feed for the bees [36].

There is a rather limited number of modern ethnological or ethnobotanical reports on the use of birch sap for food outside the former Soviet Union [2,10]. Although tree saps have been mostly used as a simple beverage, they also have medicinal and cosmetic functions $[14,37,38]$ as well as folk veterinary applications [39]. Recent research on the use of birch sap for cosmetic purposes has shown promising results [40].

The purpose of this paper is to give an overview of the use of tree saps in northern and eastern Europe (including northern Eurasia). Relying on ethnographic data, travellers' accounts and contemporary ethnobotanical fieldworks, we discuss the means of collection, preservation, food and non-food use of saps of different species, covering especially the genera Betula and Acer.

\section{Northern Europe}

\section{Denmark}

Tapping birch sap has a long tradition in Denmark. It is mentioned by botanist Simon Paulli in 1648. Later authors write that it was used not only as a beverage, but also, by adding yeast and malt, made a refreshing ale.

Birch sap has also been used for medicinal purposes [41]. It was included in the "Danish pharmacopeia" in 1772. Birch sap was recommended against hepatitis, rash, intestinal worms and scurvy [42]. Birch sap was also added when making cheese in order to protect it from vermin [43].

A perfume factory in Denmark bought $600 \mathrm{l}$ of birch sap annually in the mid-1950s and used it for making hair-water. It was also used as emergency food in times of food shortages. The sap was also used when making bread [42]. A wine made of birch sap was made by adding yeast to it in earlier days [44].

\section{Norway}

Birch sap has been tapped and used in some parts of Norway. In the medieval "Flatey book" ("Flateyjarbók"), completed in 1394, there is a description of how King Sverre and his men "spent two nights in the wilderness and had no food but sap they could suck from the trees" [2]. Norwegian writer Peder Claussøn Friis described in the 1590s from Finnmark that sap was tapped and used by herdsmen and woodcutters [45]. There are many descriptions in the topographical literature from 18th and 19th century about the use of birch sap for food in various parts of Norway. It was also used by the higher classes [2].

Children, especially, have gathered and appreciated birch sap, but adults have drunk it too. Most of the sap produced has been used as a fresh drink, but in some areas they added yeast, and in more recent times also sugar, in order to produce a kind of wine. The sap was also used when making coffee. For children it was a kind of sweet [46].

\section{Sweden}

Tapping of sap from the birch tree in the spring used to be very common in Sweden. Cartographer Olaus Magnus made a brief note in 1555 that Scandinavians were tapping birch for sap and using it as a fresh drink [2]. It is also mentioned in a medicinal handbook from 1578. Two species of birch are common all over Sweden: silver birch Betula pendula Roth. and downy birch. Betula pubescens Ehrh. Particularly the former has been used. In some parts of southern Sweden the Norway maple (Acer platanoides L.) has also been utilized for this purpose. Ethnographical records from various provinces give detailed information on the gathering and manufacturing of the sap into drinks or its use as an ingredient in various foodstuffs. A pine-wood pipe was used for the collection [47-49]. Disputes about the right to tap birch sap from trees were taken to court as early as the 17th century [2].

Birch sap has been seen as a good food ingredient and used for gruel (made of birch sap and barley meal), in coffee, and in some areas (such as northern Dalecarlia) made into ale by mixing with malt and yeast $[1,47,48]$. From Småland there is a description from 1749 saying that the birch sap ale was sometimes flavoured with bog myrtle (Myrica gale L.) [50]. At 
the end of the 19th century and beginning of the 20th century birch sap was mostly gathered and consumed by children $[2,51]$. Information concerning sap can also be obtained from literature. Poets like Carl Michael Bellman (18th century, "birch sap is my life and liquor is my health") and Erik Axel Karlfeldt (late 19th century, "the sap of the birches is spraying from drilled bark") mention the use of birch sap as a drink [1]. Birch sap was obviously not only used by the peasantry, but also by the aristocracy and bourgeoisie, something that is also proved by recipes in older cook-books. For instance urban taverns provided wine made of birch sap in the late 18th and early 19th century. Many recipes mention additives such as bog cranberry (Vaccinium oxycoccus L.) juice, barberry (Berberis vulgaris L.) juice, lemon (Citrus $\times$ limon) juice and also, if these were not available, gooseberry (Ribes uva-crispa L.) wine (Tab. 1). These recipes probably have a German origin [2].

Besides beverages, vinegar was also made of birch sap [52]. According to a Swedish translation of Wolfgangi Hildebrand's "Magia naturalis" from 1654, some birch juice should be added to cheese to protect it from worms [53].

In some parts of Sweden it was considered as famine food in the springtime. Historian Pehr Arvid Säve [54] writes that poor people on the island of Gotland used to gather birch sap and use it as a beverage. A birch tree could produce around 2 1 a day for two weeks on Gotland. During the last real famine in Sweden, in 1867, tree-sap was widely used in the southernmost part of Sweden, for bread, gruel and as a mealtime drink. Birch was therefore referred to as the "poor-man's cow", according to one record from southern Sweden [10].

Birch sap has also been used among the Saami in Sweden, especially among the Forest Saami in Västerbotten. It was used when making gruel. The Saami also used the sap and inner bark from pine (Pinus sylvestris L.) and spruce [Picea abies (L.) Karst.], particularly the former. It was gathered in early spring. It was dried into flour which was eaten with milk and fat [55].

Maple sap was occasionally gathered as well, for instance in Öland, where it was still collected in the 1930s [2].

As in many other northern and central European countries, there is a renewed interest in using birch sap also in Sweden. Small-scale production of bottled sap exists. Every year courses are run in order to develop an interest for this non-timber wood product.

Birch-wine is also mentioned in several 18th and 19th century texts [56-60]. Wine from birch sap is nowadays made by some home producers, but also by small companies working with local products and gastronomic food. Most famous is the "Grythyttan Björkvin", a rather expensive sparkling birch-wine, developed from an old recipe from 1785 . It is produced by a small company in Jämtland and sold by the government owned chain of liquor stores (Systembolaget).

\section{Finland}

In Finland and Carelia birch sap was tapped off in the spring and used as a refreshing drink [61,62]. The Saami in Finland also made a refreshing beverage of birch sap $[63,64]$. The silver birch (B. pendula), especially, has been harvested. Tapping birch trunks has a long tradition and was regarded as an important commodity in early modern times. Various techniques were used to collect the sap [65]. In eastern and northern Finland sap was also gathered from the birch tree stumps by making a pit in it. There is a dissertation from Turku in 1759 describing in detail the use of birch sap in Finland. It was obviously widely used both by the peasantry and the nobility. Sap was not only used
Tab. 1 Additives for the fermentation of tree saps.

Additives

Regions used (time)

$\begin{array}{ll}\text { Anethum graveolens L. (stems) } & \text { BE } \\ \text { Avena sativa L. (sprouting grain) } & \text { LT } \\ \text { Berberis vulgaris L. (fruit juice) } & \text { SE } \\ \text { Carum carvi L. (dried fruits) } & \text { EE (all the time) } \\ \text { Citrus } \times \text { limon (juice) } & \text { BE, SE, UA (commonly nowadays) } \\ \text { Citrus } \times \text { limon (peels) } & \text { EE (last } 80 \text { years), FI (18th century) } \\ \text { Fabaceae (beans) } & \text { RU } \\ \text { Hordeum vulgare L. (roasted grains) } & \text { UA (now and in the past) } \\ \text { Juniperus communis L. (twigs) } & \text { EE (all the time) } \\ \text { Malus sp. (dried fruits) } & \text { UA (now and in the past) } \\ \text { Myrica gale L. (herb) } & \text { SE (18th century) } \\ \text { Prunus sp. (cherry fruits) } & \text { BE } \\ \text { Pyrus sp. (dried fruits) } & \text { UA (now and in the past) } \\ \text { Quercus robur L. (bark) } & \text { BE } \\ \text { Ribes nigrum L. (twigs) } & \text { EE (all the time), LT (new) } \\ \text { Ribes uva-crispa L. (wine) } & \text { SE } \\ \text { Syzygium aromaticum (L.) Merrill \& } & \text { FI (18th century) } \\ \text { Perry (flower buds/clove) } & \\ \text { Vaccinium myrtillus L. (juice) } & \text { BE } \\ \text { Vaccinium oxycoccus L. (fruit juice) } & \text { SE } \\ \text { Vitis sp. (rasins) } & \text { EE (last 50 years), UA (commonly } \\ \text { (Rye) bred } & \text { nowadays) } \\ \text { Grains (barley, oats), flour (barley, } & \text { EE (until mid-20th cent), FI } \\ \text { oats, rye) } & \text { (modern), LT } \\ \text { Maltose } & \text { SE, FI, RU } \\ \text { Sugar } & \text { BE, EE (recent), NO, UA } \\ \text { Wax } & \text { RU } \\ \text { Yeast } & \\ & \end{array}$

BA - Bosnia and Herzegovina; BE - Belarus; BG - Bulgaria; CZ - Czech Republic; DK - Denmark; EE - Estonia; FI - Finland; GE Germany; HU - Hungary; LA - Latvia; LT - Lithuania; NO - Norway; PL - Poland; RO - Romania; RU - Russian Federation; SE - Sweden; SK - Slovakia; SI - Slovenia; UA - Ukraine; UK - Scotland and England.

as a fresh drink but also as beer. It was naturally fermented and could be used during the summer. The dissertation describes how the sap was used for manufacturing syrup, sugar and other goods. It also gives a recipe for birch sap-wine flavoured with cloves and lemon peel [66]. When Swedish historian Nils Reinhold Broocman visited the Governor of Villmanstrand (Lappeenranta) on the shore of the Lake Saimaa in 1754 he was served sparkling wine made of birch sap [2].

Birch trees were regarded as private property and individual trees were even given names (similar to names of cattle) in the area of Vyborg in south-eastern part of the country. The month when the birch gives sap is known as "mahlan aju" or "mahlakuu" in the Finnish folk calendar. This name for the month of April is used in dictionaries by the priest Christfrid Ganander in the late 18th century and by philologist Elias Lönnrot in the mid-19th century, but has also been recorded later [67].

In south-western Finland a kind of ale was made of birch sap mixed with flour and malt [68]. The Dutch diplomat Anthonis Goeteeris noticed as early as 1616 that birch sap was 
used for brewing beer in Finland [53]. A recipe of traditional birch sap beer from northern Carelia is given by Räsänen [69].

A questionnaire about the use of birch sap was sent out in 1963 and the answers show that it was still tapped in the central and south-western part of the country [65]. A renewed fashion for tapping birch sap has been seen since the 1980s. Currently there is an increasing interest in birch sap as a non-timber forest product, both from researchers and new product developers. Birch water and syrup made of birch sap is available in well-equipped Finnish stores.

Norway maple (A. platanoides) grows only in the southernmost part of Finland, and it was therefore more seldom used [68].

\section{Estonia}

In Estonia, birch and Norway maple sap has been widely collected for as long as can be remembered. April was known as "mahlakuu" ("sap month") in some parts of Estonia. This name was recorded in 1660 by linguist Heinrich Göseken, who wrote "Aprilis Maala kuu / â fluxu betularum arborum, qve in illo mense fluunt" [70].

In his travelogue from 1615 Adolph Nickolaus von Steinkallenfels describes the gathering of birch sap in Estonia [71]. Linguist August Wilhelm Hupel describes, in 1777, that birch sap was used for making a fresh beverage, but also for making wine and vinegar [72]. Birch sap was not only gathered by ethnic Estonian peasants, but also by Swedish-speaking coastdwellers [73,74]. The Setu people in south-eastern Estonia also gathered birch sap [2]. In the South Estonian dialect there is a special word for sap-tapping: "tikkama" $[75,76]$.

Norway maple (A. platanoides) is less common in Estonia and people did not dare to spoil their yard trees except on the islands of the Baltic Sea, where maple sap is considered "the right sap", while birch sap is not appreciated. However, there are records that boys used to tap maple sap illegally from trunks in manor parks in mainland Estonia [74]. The maple tapping time period was before the snow melted, while birch sap was foraged after the snow was gone. Among common people B. pendula has been the preferred sap-tree, although it gives less sap that $B$. pubescens, as it was believed that its sap is sweeter. However, the experiment showed that $B$. pendula gives 158-282 1 in 20-27 days and contains less sugar than $B$. pubescens, which gives 67-151 1 in 31-38 days and Acer platanoides 19-32 1 in 32-38 days [77]. It was also believed that a tree growing on a hill had sweeter sap (Fig. 1). Sap was collected using a wooden or metal spout in a drilled hole, but also by striking a scythe in the trunk. A collecting container was placed under the dropping spout and changed as it filled up [78].

Starting from 1972, centralized collection of birch sap was organized through state forest enterprises (Fig. 2). The plans for collecting were fixed, the quality standards for chemical and physical qualities were established, the techniques of collection changed, and opened containers were replaced by relatively hermetic collecting [79]. Two food-factories stocked up and processed sap, adding bog cranberry (Vaccinium oxycoccos L.) or quince [Chaenomeles spp.] juice, as well as sugar, and sold it in the shops [12,80]. In addition, the birch sap was used to produce shampoo. Over 30 tons of birch sap were collected in 1976 for that purpose [12]. In modern Estonia a few men of enterprise have found use for larger amounts of semi-industrially gathered birch sap in the form of the birch vodka "Kaseviin" and birch wine; also fresh birch sap is sold locally or exported to Italy [81].

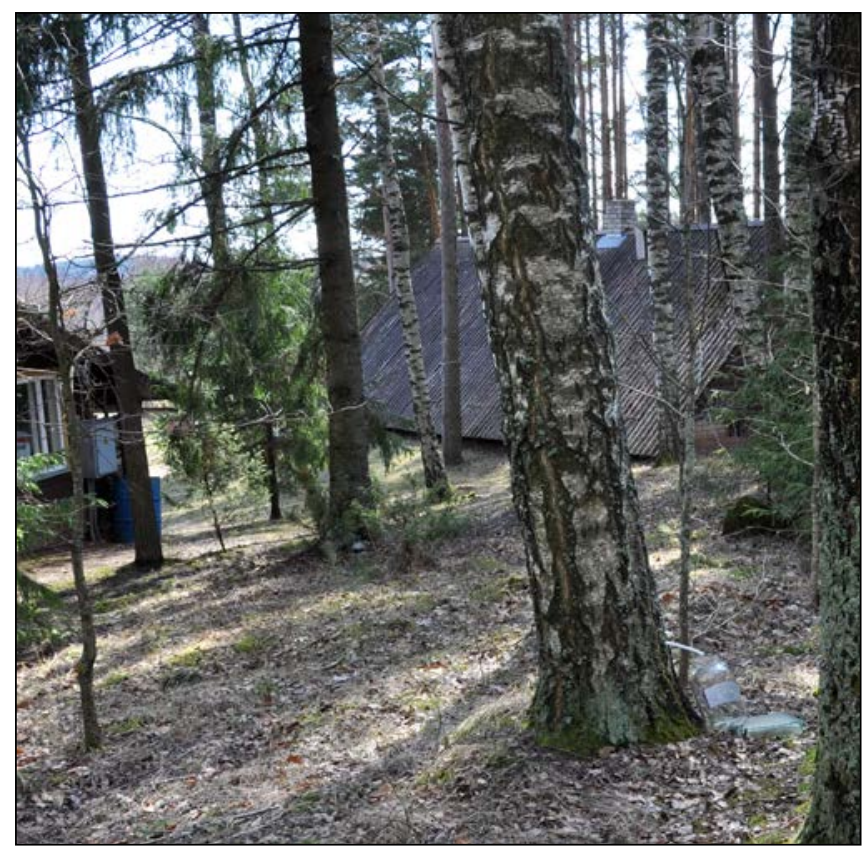

Fig. 1 Birch sap is preferably collected on the hills, often near homesteads. Kambja, Tartu County, Estonia, in 2012. Photograph: Raivo Kalle.

With the fall of the Soviet Union, collecting birch (and less frequently Norway maple) sap still remained an important activity for rural people. In spring every year newspapers re-introduce the techniques of collecting and using birch sap. The majority of the population know the taste of birch sap. Historically, most of the maple and a lot of birch sap was used fresh, for drinking and making food (instead of water for tea, soups, and porridges) [82]. When there was a shortage of sugar, particularly during wartime, the tree sap was used to make syrup for sweetening food [12,77]. For some families making syrup is still a kind of ritual entertainment.

The main means of preserving birch sap was through alcoholic fermentation. Besides the plain sour drink that was kept for months in the cellar and used during hay-making, different drinks were produced, like kvass (light ale), beer, and mead. For the fermentation, different additives were used, like twigs of black currant (Ribes nigrum L.) and juniper (Juniperus communis L.), caraway fruits (Carum carvi L.); and later also

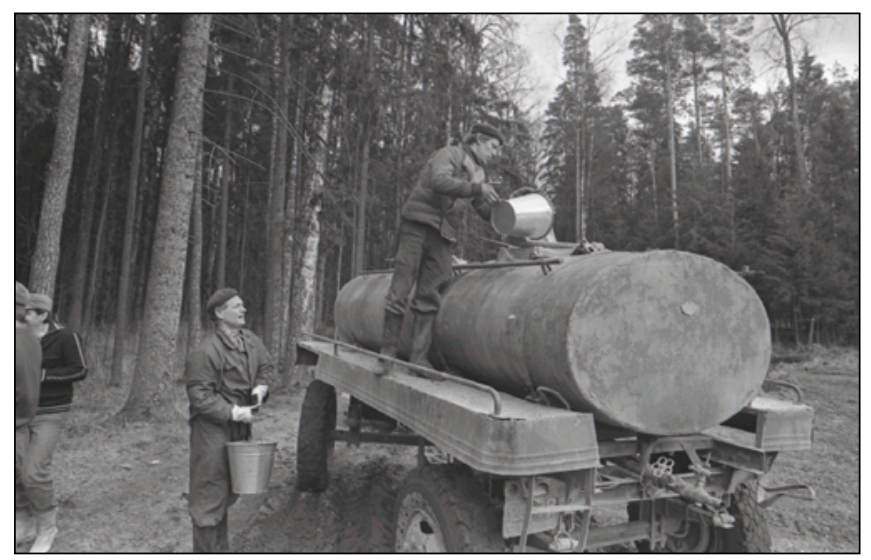

Fig. 2 Collecting of birch sap for the food industry in the early 1990s, the last years of Soviet regime, Tiksoja, Tartu County, Estonia. Photograph: Lembit Michelson (EFA.204.0-169211). 
raisins and lemon peels. Sometimes, grains or flavour were added after fermentation, to produce specific kvass [12,83]. Although detailed recipes on how to make wine and sparkling wine from birch sap were published as early as the end of the 18 th century $[72,84]$, there is no trace of their imitation in ethnographic data. When in the beginning of the 20th century soft drinks became available in shops, the consumption of fresh birch sap dropped considerably [82]. In the 1970s (and even later), birch-sap was processed and was used not only at hay-making time in summer $[13,85]$. Fermented birch sap is still perceived as a hay-time drink, but many rural households, also without cattle, prepare birch-sap for beverages. Nowadays the fresh birch sap is stored in freezers and is used for instance in the sauna.

The cosmetic use of birch sap was widespread in Estonia. In the 19th century it was believed that one who washes his or her face with the first drops of birch sap will get rid of freckles and their face will stay pale all the summer. Fair skin was valued among the peasantry, as well as among the landowners. It was also said that if one washes the eyes with the first drops of birch or maple sap it will keep them clean and healthy. Sore eyes were treated with birch and maple sap compresses. There are a few reports of using birch sap for treating specific skin diseases [86].

There are also a few reports on the use of other tree species for tapping sap. Folklorist Oskar Loorits [87] has a mid-20th century record of using thicker rowan trees (Sorbus aucuparia L.), a few other authors [12,82] mention the tapping of its sap. Ethnographer Aliis Moora [82] also reports the tapping of linden (Tilia cordata L.). Recent field work report the modern use of sycamore maple (A. pseudoplatanus) on Hiiuma Island. The latter taxon is probably more widely used than was earlier reported, since this maple is widespread in Estonian urban vegetation.

\section{Latvia}

As in the other Baltic countries there is a long tradition of drinking birch sap in spring and making beverages from it to be consumed in the months of summer heat. The month of April is known as "sulu mēnesis" in Latvian and "kõlimkū" in Livonian, both meaning "birch sap month", indicating that sap was gathered at that time [88]. Latvian ethnologist August Bielenstein [89] gave a detailed description of the traditional gathering and manufacturing of birch sap among the Latvians (Fig. 3).

Also the Livonian people of northern Latvia had a name for April meaning "birch sap month". They tapped the birch in spring-time and the sap was fermented in a large vessel [90].

Tapping birch sap has been a common by-product in the Latvian forests up until the present day [91]. In the Soviet period Latvia was one of four grand industrial collectors of birch sap in the Union [12]. Birch sap is important in contemporary Latvian culture. Wine and other products made of birch sap are available in stores. Birch sap from Latvia is exported frozen and available in many countries.

\section{Lithuania}

Birch sap was gathered in large quantities in the 1830s and 1840 s by the Lithuanians. It was used both fresh and fermented [92]. In some parts of Lithuania, birch and Norway maple sap was fermented into a kind of refreshing beer (similarly as in Belarus and Ukraine), at least up until the mid-20th century [93].

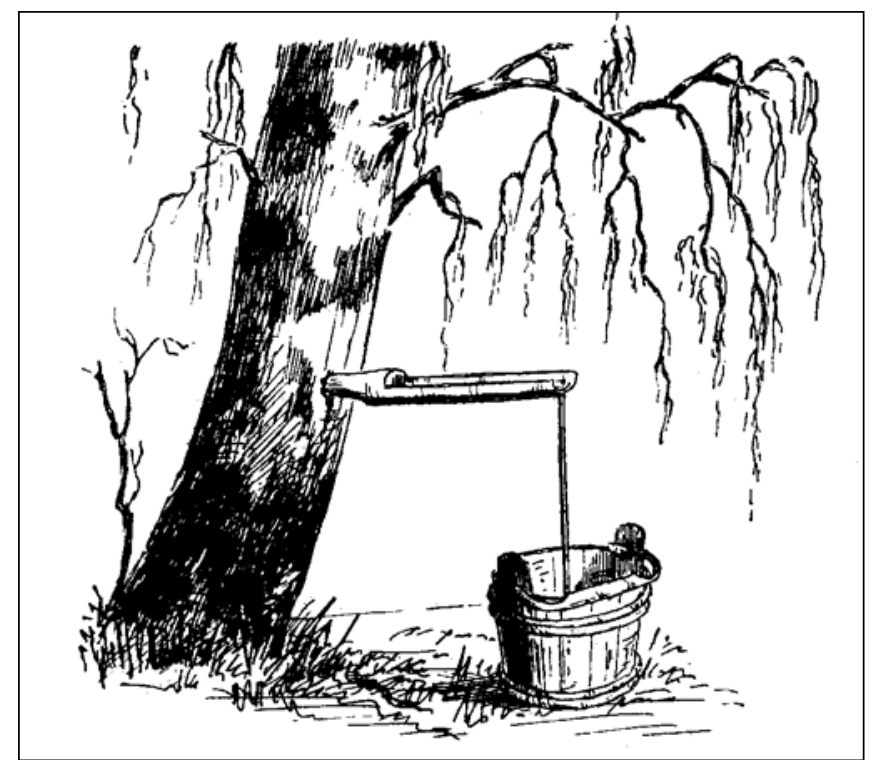

Fig. 3 Way of tapping sap from Birch in Latvia in the late 19th century. From Bielenstein [89].

In modern Lithuania, sap is gathered from Norway maple (A. platanoides) or birch (B. pendula, rarely also B. pubescens). Usually, old and thick trees are used for extracting the sap, and every year the same trees are used. The most common procedure is to drill a hole into a tree trunk at a height of about 50 $\mathrm{cm}$. A small wooden gutter (nowadays metal or plastic tube) is inserted into the hole and the sap leaks into a bucket beneath. Maple sap starts flowing in early spring, around March. It is easily checked by breaking off a small twig; if the breakage becomes wet and even starts to trickle it is time to start. The time is described traditionally "after snowmelt but still with frozen ground". The maple gives 3 to 51 per day. The sap flow depends on weather conditions and lasts from few days up to 3 weeks. While early sap is clear, at the end it becomes dreggy and tends to ferment sooner. Due to the sweet taste, the small amount and the fact that this is the very first fresh food received from plants in the year, maple sap is consumed immediately and is not conserved. When maple sap is finished, one can proceed with birch sap. Again, readiness can be tested by breaking a twig or looking at a fresh tree stump. Birches are much more generous: 10 to 15 l out of one hole per day is the revenue for a relatively old (ca. 60 years) birch tree. The bough is cut, or twig broken, and a jar attached. As birches are very common, large amounts of sap were/are extracted and preserved. Additional ingredients may differ: grains of barley or oats, peas, rye flour, a chunk of bread. Especially oats soon sprout shoots and the germinated grains form a solid cover. After a few months - usually during hay-making - this cover is removed and the fermented sap is consumed. It is commonly believed to have revitalizing properties. Ethnologist Vacys Milius [94] mentions the use of twigs of black currant, Ribes nigrum L., for sap conservation. He believes this is a rather recent innovation. Birch sap has also been used for washing hair [95].

\section{Scotland and England}

The sap of trees has also been collected in Scotland. Several species have been utilized for this, such as birch (B. pendula), ash (Fraxinus excelsior L.), field maple (Acer campestre L.) and sycamore (A. pseudoplatanus). The harvesting of birch sap took place in March. The tap was usually made of a hollow elder 
twig or a grooved peg. A good tree could produce as much as two gallons (approx. $7.5 \mathrm{l}$ ) in a single season [96].

The sap was used as a fresh beverage, and sometimes it was made into wine. English gardener Moses Cook gave, in 1675, a quaint recipe for making wine of birch sap [88]. Birch sap was considered to have medicinal qualities. According to Scottish folk medicine it was used in preventing baldness. Queen Victoria is said to have drunk large quantities of birch sap when she was at Balmoral Castle, in order to halt the thinning of her hair [97]. In the Scottish Highlands ash sap was given to newborn children as their first nourishment and in Ireland and England to treat earache [98].

Birch trees were traditionally still tapped in the Highlands as late as the late 1940s, as a rule, the sap was boiled down to make a sweetmeat [8]. However, birch tapping appears, as in other parts of northern Europe, to be making a comeback in Scotland [97].

We also have a few notes from various parts of England where birch sap used to be tapped, for instance from Montgomeryshire, Hampshire and Yorkshire. The trees were tapped in February or early March [2].

In Lincolnshire and the Highlands birch sap wine was made and used as a tonic and for treating rheumatism. The trees were tapped for a few days only in order to not exhaust the tree [99].

\section{Central Europe}

\section{Czech Republic}

The month of March is called in Czech "brrezen" - "the month of birches". Tapping sap from birch, maple and beech (Fagus sylvatica L.) is described from the Bohemian Forest. The best sap came from the birch, though. In some areas of Bohemia young girls and boys used to gather on 23 March in order to tap birch sap. This was celebrated by eating food and dancing around a birch. The girls consumed the birch sap in order to be healthy and, as grown-up women, fertile $[4,100]$.

Disabled persons went in secret to a birch-tree on the first day of March to cut the bark and to put a piece of linen with a drop of blood into the incision. If the bark inosculated, the impairment was said to be healed. The sap harvested on that day was also assumed to have healing power: it was drunk for good health, against infertility, etc. [101]. Girls washed themselves with birch sap to be beautiful and not to have freckles. Some of them also drank it to be healthy and to have many children in marriage [102].

\section{Germany}

Birch sap has been used as medicine among the Germans, especially against lung diseases and gout. Physician Hieronomys Bock describes, in his "Kreuterbuch" (1551), its medicinal use. In the 1880s birch sap was still harvested in the Harz Mountains and in the Thuringian Forest [2]. It was also still used as a cosmetic in the early 20th century [103]. Birch sap was still gathered in East Germany in the 1980s (Fig. 4).

\section{Poland}

According to a plethora of ethnographic sources, the use of birch sap (mainly from $B$. pendula, more rarely from $B$. pubescens), was widespread in the 19th century. It was usually drunk fresh, extracted by drilling a hole and making a little trough or pipe from wood, or by breaking a branch. In the mid-20th century this use was (nearly) obsolete in most parts of Poland or practiced mainly as boys' spring entertainment [104-108]. The use of birch sap was most intense and widespread in eastern parts of the country (e.g. Podlasie and Mazovia regions). Processing of birch sap was carried out relatively rarely but is documented in a few regions at the turn of the 19th and 20th century. For example, in the Kozienice Forest (central Poland) it was boiled with rye flour and milk [109]; in the Kurpie region (north-east Poland) birch syrup was produced by boiling off the water from the sap, and used as food sweetener [110]. Birch sap has never been sold in Poland on a large scale; it is only available in health food shops, as a kind of curiosity.

Norway maple (A. platanoides) sap was extracted very rarely in Poland, mainly in its eastern part, and, after 1945, in the territories of west and north-eastern Poland, where the settlers from the present Lithuania and Belarus were moved. It was usually drunk fresh, although the inhabitants of the village of Wrzosy (north-east Poland, Polish immigrants from Lithuania) made a fermented drink out of it $[93,105,107]$. Sycamore $(A$. pseudoplatanus) sap was also occasionally drunk, only fresh, mainly in SE Poland $[105,107]$.

Very rarely a few other species of trees were used to obtain sap, drunk in the fresh state, these were mainly hornbeam (Carpinus betulus L.), linden (Tilia spp.), sour cherry (Prunus cerasus L.) and wild bird cherry (P. avium L.) [104,107].

\section{Slovakia}

Birch (B. pendula) and maple sap were commonly drunk fresh by Slovaks (mainly boys) in 19th century Slovakia [111-113]. Only the Latin name of field maple (A. campestre) is mentioned in ethnographic sources [111,112], but sycamore (A. pseudoplatanus) was probably commonly used as well.

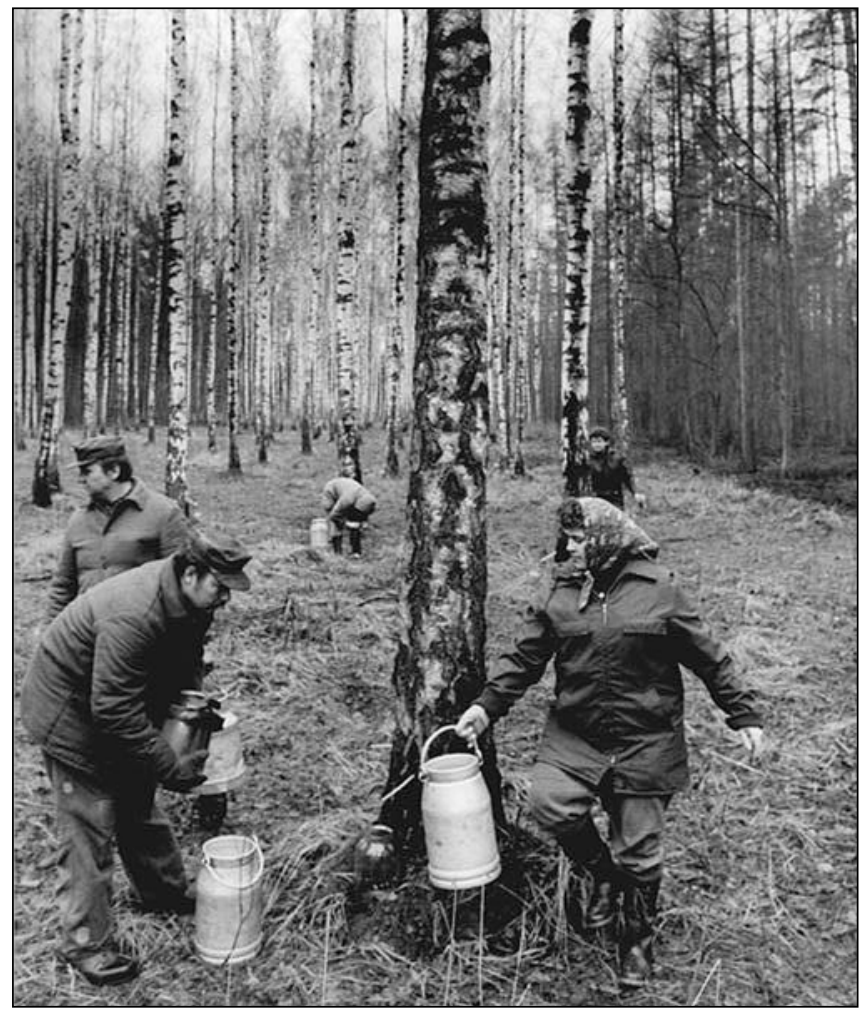

Fig. 4 Tapping birch sap in Colditz, near Leipzig, in East Germany in April 1985. Photograph: Wolfgang Kluge. Source: http://de.wikipedia. org/w/index.php?title=Datei:Bundesarchiv_Bild_183-1985-0404003,_Colditz,_Birkensafternte.jpg\&filetimestamp=20081204095223 
Attempts were made at the beginning of the 19th century to make sugar from maple species (following the North American example) on an industrial scale in the present territory of Slovakia, but later they were abandoned [114].

\section{Eastern Europe}

\section{Belarus}

In Belarusian, March is called “сакавік” [sakavik], "the month of sap". Some historical data on the use of tree sap in Belarus are present in Rostafiński's ethnobotanical questionnaire of 1883. A few of his respondents reported that the use of both Betula spp. and Acer platanoides sap was very common there. One of the ways of utilizing the fermented birch and Norway maple sap was boiling it into soup with young shoots of Aegopodium podagraria [107]. There is also 19th century information that sap from European aspen (Populus tremula L.) was gathered by the Belarusian peasantry [104].

Although it was a popular beverage, it was supposed that one may fall ill with fever having drunk sweet birch sap. In the Brest Region people believed that someone who drank birch sap would have lice [115].

In 1972 Belorussia was the third biggest birch sap producer in the Soviet Union, lagging behind only Ukraine and Russia [12]. There it was suggested that sap can be tapped from mature birch forests for three years before clear cutting, with an estimated yield of $40000 \mathrm{l} / \mathrm{ha}$ [116]. Nowadays in the European part of the former Soviet Union birch sap is often sold with lemon juice added. Although this practice is of relatively modern origin it was already reported in Rostafiński's ethnobotanical questionnaire of 1883 in the Belarusian Polesia region (lemon juice and sugar was added and the bottle was closed for 2-4 weeks) [107]. In the times of the Soviet Union a recipe of Belarussian origin was published, it described making kvass with a long storage time: birch sap was closed in a vessel with rye bread, oak bark (Quercus robur L.), cherries (Prunus sp.) and dill stems (Anethum graveolens L.), with no yeast added [117].

In modern Belarus birch sap collecting is regulated by state rules, and all industrially produced sap has been collected by producers authorised by the state. In 2011 over 25000 tons of birch sap was collected, according to a report by the Belarus authorities [118]. Part of it is industrially processed and exported in carton packages with different additives (e.g. Vaccinium myrtillus L.) to many European countries (e.g. Germany, France and Baltic States).

Belarusian citizens have the "right to collect birch sap for their own use in the places, allocated for this purposes by the legal entities conducting forestry. It's necessary to apply to the forestry organisation at the place of domicile. [...] Birch sap may be collected in specially protected areas provided it is allowed by the protection and use mode for these territories" [119].

\section{Russian Federation}

The English botanist John Tradescant the elder who travelled to Arctic Russia in 1618 observed in the vicinity of Arkhangelsk that the peasantry gathered birch sap and used it as a fresh drink [2]. Early information about sap production and utilization can also be found in a Russian manuscript from 1768. People have traditionally used the sap as a fresh drink as well as for making wine, vinegar, syrup, kvass and confectionery [120,121]. Russian ethnographer Dmitri Zelenin [122] describes the various ways birch sap was utilized by the Russians. It was drunk fresh, but also fermented by adding malt, wax, beans or rye bread. Also Norway maple sap (A. platanoides) was gathered. In the 1890s, the peasants in the Vologda area still gathered sap from the Scots pine (P. sylvestris) [104].

In the Perm region birch sap was consumed as a beverage and used externally against sores on the shanks. To make ointment, one took two bottles of the sap and 0.061 of ethyl alcohol and evaporated it on a small fire until the liquid became syrup. The extract was spread on a cloth and put on the sores. In the Transbaykal region the freshly harvested birch sap was given to children with milk during the teething period [123].

Not only the Russians but also many other ethnic groups living within the territory of Russia used sap. Votes, Izhorians and Vepsians, who lived in the Saint Petersburg Governorate at the end of 18th century, used maple sap for making syrup. Birch sap was drunk fresh to improve the health and made into sparkling drinks and vinegar [124]. The Mordvinian used the thickened sap as food. It was also used for medicinal purposes [125]. It was also known as a beverage among ObUgrians [63]. Birch sap for washing faces was still used among Estonian settlers in the Omsk region at the end of 20th century [86]. Yukagirs living in eastern Siberia are known to have utilized the sap of poplars (Populus sp.) and willows (Salix sp.) [126]. The German botanist and explorer Johannes Gottlieb Georgi [127] writes that the Bashkirs used birch sap water as a refreshing spring beverage. Tofalars and Altays living in the Altay area used thickened birch sap as a sweetener in tea [10]. Ethnographic data on the use of birch sap also exist from many other ethnic groups in Siberia and Russian Far East, such as Evenki, Itelmens and others [1,5,128].

In Soviet times natural and preserved birch sap, birch sap with sugar, “Берёзка” (birch) and “Весенний” (vernal) drinks, birch kvass and maple drinks were available on the retail market while saps with herb and pine needle extracts were widespread [129]. In perfumery and the cosmetics industry birch sap was added to lotions and shampoos [22,35].

Industrial sap collecting in the Soviet Union started in Kazan in the 1920s. In 1937 over 300 tons of birch sap were collected for making wine and kvass in Sverdlovsk [35]. At the end of the 1980s the annual sap production reached more than 70000 tons [129]. Four species of birch (Betula costata Trautv., B. pendula, B. platyphylla Sukaczev, B. pubescens) are used for tapping sap in Russia [130]. Daily birch sap extraction ranges from 0.9 up to 13.5 and equates in average 4-5 l per tree of $B$. pendula, B. platyphylla and B. pubescens [121]. Korean birch (B. costata) appears to be of the highest sap productivity (50-78 1 per day) as compared with the other birch species [131]. The amount of sap produced depends on the size of the tree, so values given by different authors may vary from a few to a several dozen litres.

After the collapse of the Soviet Union the former birch sap production was completely shut down [132]. However, some regional authorities have recently undertaken efforts to restart birch sap production. For example, the government of the Khabarovsk region has developed such a program [133]. The technology of sap tapping and production specification for "Натуральный березовый сок" (natural birch sap) and “Дальневосточный березовый сок с сахаром" (far east birch sap with sugar) have been developed $[132,134]$. 
At the end of the 20th century, Russian researchers proposed the use of coniferous cell sap [129] and phloem sap [135] as prospective substances for medicine, cosmetics, agriculture, household chemicals, etc. Such tree species as Pinus sylvestris L., Picea abies (L.) Karst., Abies sibirica Ledeb., Tilia sp. and Fraxinus sp. were considered to be the most productive for sap tapping.

\section{Ukraine}

In Ukrainian the month of March is known as “березень” [berezen'] - "the month of birches". In Ukraine birch sap is widely used and sold in shops. In 1972, while in the whole of the Soviet Union around 25000 tons of birch sap was industrially collected, the share of Ukraine was 20000 tons of birch sap [12]. It is usually drunk fresh, pasteurized, often with lemon juice. Traditionally it was fermented in wooden barrels with dried fruits (apples and pears) and/or roasted barley added to it. It lasts as long as late summer, and was drunk as a refreshing drink during hay-making and cereal harvest. Nowadays a variety of additives are used, mainly lemon juice, raisins and/ or sugar. The use of birch sap decreased after the Chernobyl nuclear catastrophe localized in the main birch sap region of Ukraine, and nowadays some people still tend to make the sap themselves and not buy in the stores out of fear of drinking radioactive sap [136].

Every year the beginning of the collecting season is announced by the media as important news. Short films made during sap collection and recipes for sap preparation and use are quite popular on Ukrainian Internet sites. A large share of commercial sap collection (made by forest enterprises) is exported. The results of a recent study, 2012, on birch sap use in some villages in the Vinnytsia Oblast of Ukraine, conducted by ethnobotanist Iwona Kołodziejska-Degórska, show that both $B$. pendula and $B$. pubescens are used, a variety of sap extraction methods are used (e.g. pipes drilled into the tree, even made from ball pen tubes; one or two cuts with a tube, a grass stalk or a metal sheet bent into a V-shaped rut underneath etc.; Fig. 5, Fig. 6). Most people collect only small amounts (up to $10 \mathrm{l}$ ) into plastic bottles (Fig. 7) and use the sap mainly in the fresh state, although the traditional methods of fermentation are still known and used by some individuals and birch sap collection remains an important annual activity. In spite of earlier reports on non-food uses of birch sap in the region, such as medicinal (treating skin diseases internally and externally), a source of vitamins (especially for children), as a diuretic [137] and cosmetic (to remove freckles [138]) none of research participants reported them. For commercial collection of sap plastic bags and glass $3 \mathrm{l}$ jars are used.

\section{Southeastern Europe}

\section{Bosnia, Carinthia and Slovenia}

The use of birch, maple and European beech (F. sylvatica) sap by herdsmen has been reported from Bosnia [4]. The review of edible plants of Bosnia and Herzegovina mentions only two species of trees whose sap is used: A. platanoides and A. pseudoplatanus [139].

Nobleman Johann Weikhard von Valvasor describes in his famous "Die Ehre de $\beta$ Hertzogthums Crain" [140] from Carniola that a healthy beverage was made of the birch sap. Birch sap was still gathered around Logatec in Inner Carniola

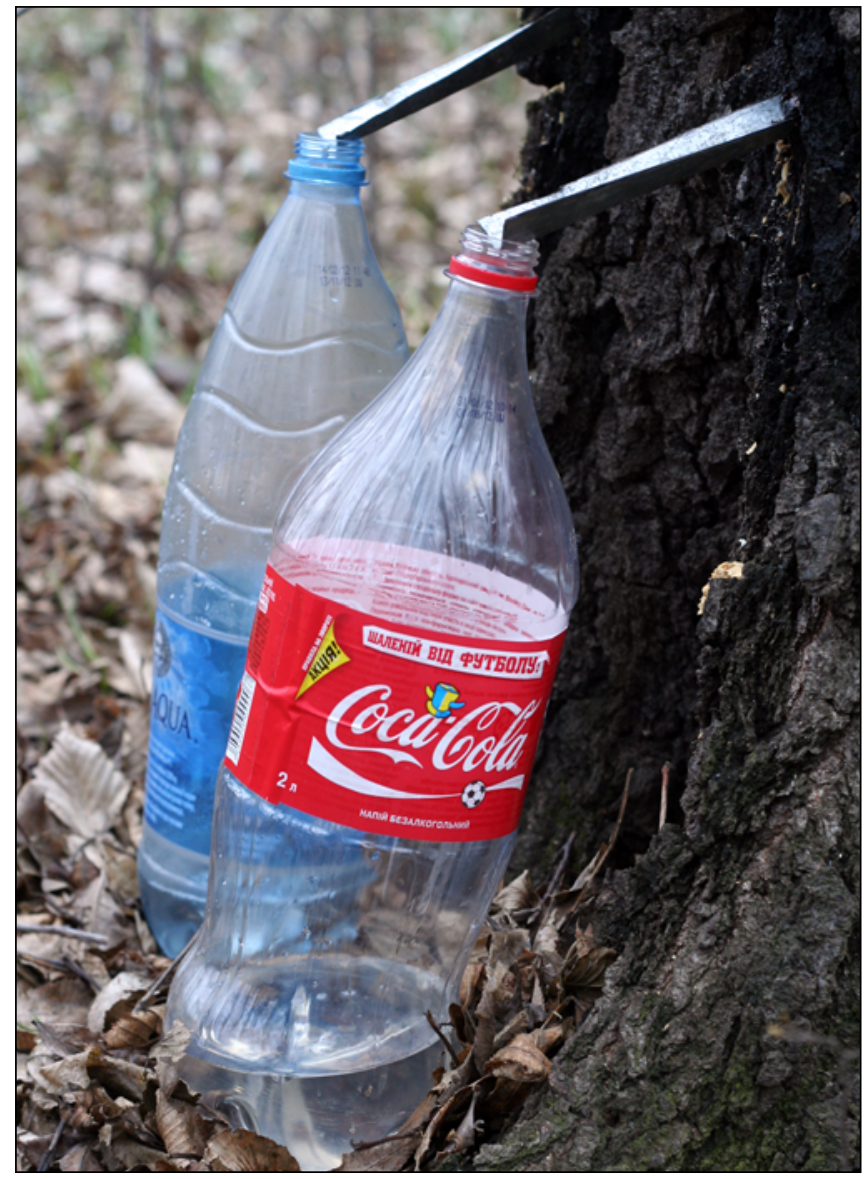

Fig. 5 All over Ukraine birch sap is collected into reused plastic bottles, Vinnytsia Oblast, 2012. Photograph: Iwona Kołodziejska-Degórska.

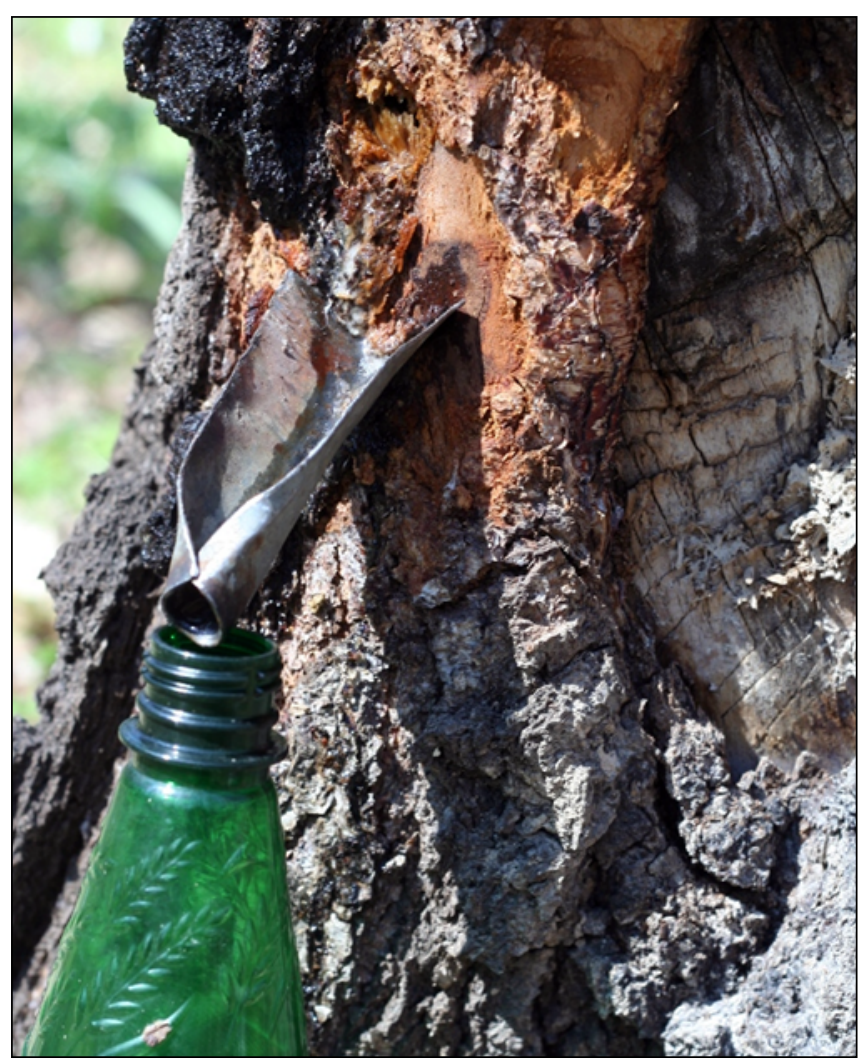

Fig. 6 V-shaped metal spout used in Ukraine, Vinnytsia Oblast, 2012. Photograph: Iwona Kołodziejska-Degórska. 


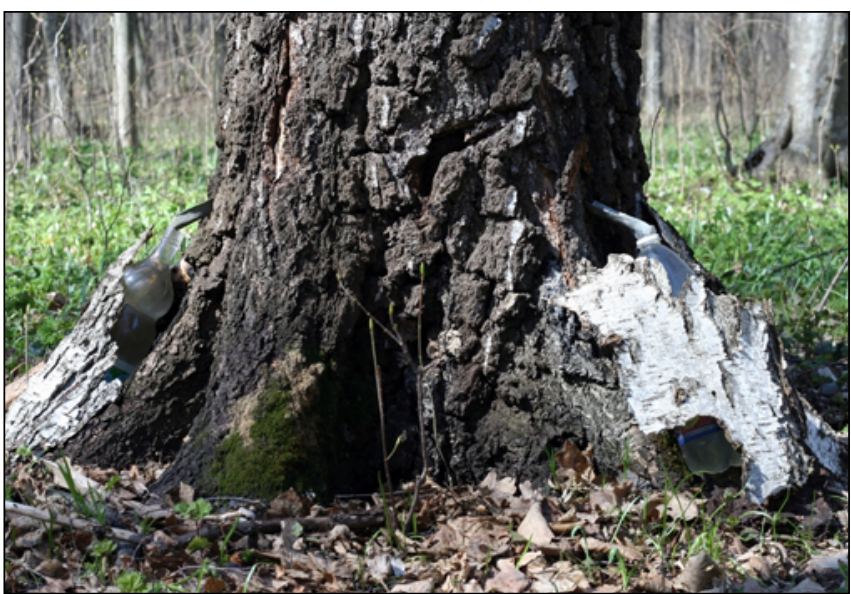

Fig. 7 Bottles covered with birch bark are protected from the sun and are more difficult to spot in the forest, Vinnytsia Oblast, 2012. Photograph: Iwona Kołodziejska-Degórska.

in Slovenia in the mid-20th century [141]. There are records of tapping birch-sap from the Carinthian Slovenes in neighbouring Austria from the end of 19th century [142].

\section{Bulgaria}

In the literature there are some data on the use of sap from Tatar maple (Acer tataricum L.). The sweet juice is used as food reinforcement, especially for children and young people. Juice flowing from the stems of plants was collected, filtered and compressed. The time of tapping, methods of processing and applications are not specified [143]. Recent field investigations show that tree saps are generally used for medicinal purposes. For instance, rubbing of the roots of the hair with birch (Betula pendula) sap is believed to help hair growth.

The reason for the limited use of birch and maple in traditional food and folk medicine among Bulgarians is their fragmented distribution throughout the country. However, grapevines (Vitis vinifera L.) are sometimes tapped for their sap. In the Rhodope Mountains on the eve of St. George (6th of May) the grapevine plants are trimmed and sap is collected. In the morning women smear their hair with this sap and throw the rest in a field of barley to grow their hair long as the cereal. It was also believed that grape sap cured sore eyes. Sometimes the sap is collected in glass bottles for medicine when needed $[144,145]$. The sap is used against dry eyes, and also to remove pigmentation and freckles. Grape vine sap is used against gallstones and bladder stones, boiled in wine. In folk recipes drops from cut branches are called "tears" of vine.

Purulent lichens are treated by brushing them with Cornelian cherry (Cornus mas) sap [142]. The juice of the injured stem of ash (Fraxinus ornus, Fraxinus excelsior) is used as a laxative [143-145].

\section{Hungary}

Tapping trees for sap used to be common practice in all forested parts of Hungary. In the north-eastern part of the country, in the so-called "Nyírség" (meaning: "landscape with birch forests"), which was rich in birch trees, collecting birch sap ("birch-water") had been an important way of making money. Hawkers had taken it, in barrels, into the neighbouring cities [146,147]. Birch-sap collection occured in other places too, but no sources mention its collection in commercial quantities [148-158].
Most of the forests of Hungary are turkey oak and hornbeam-oak forests - B. pendula is only a rare accompanying species. Where birch occured, it was tapped in the spring. The sap was drunk by herdsmen, forest-workers, only later by children as a delicacy.

Besides B. pendula, the sap of Turkey oak (Quercus cerris L.) $[150,154,156,159,160]$, sycamore (A. pseudoplatanus) [152,153], hornbeam (Carpinus betulus) [149], and wych elm (Ulmus glabra Huds.) [160] was also collected [U. glabra, being a rare species, may be false data, field elm (Ulmus minor Mill.) is more common]. In the floodplain of the river Drava an Ulmus species - presumably European white elm (Ulmus laevis Pall.), which is a common tree in today's floodplain forests - mentioned as "híres szilfák" (“elm celebrities” [161]) was also tapped. Tapping was performed with axes or gimlets; sap was blown or sucked out using reed, elder or nettle stems.

Where water-springs were rare, tree sap was the only drink for herdsmen. The sap of Q. cerris was drunk from the early spring until the beginning of frost. Herdsmen in Somogy county built permanent taps into the oaks giving the best sap. The best sap was like "good brown beer", it even frothed. These oaks had been visited for up to 20 years. Taps made of elder stems had grown into the tree-trunk over the years. Turkey oak could also be tapped through the chill cracks; if tapping was performed skilfully, sap spurted out $[154,156]$. Chill cracks are long vertical cracks formed when superfluous saps freeze inside the tree in the freezing weather. They often occur in $Q$. cerris growing in mesophilous sites too wet for this species.

Birch sap was drunk as a refreshment, and it was also considered an appetizer. It was taken against stomach and lung illnesses, women used it as a cosmetic, especially against freckles. Vinegar and beer was brewed, wine was fermented from sap [147]. Birch sap was also used for coagulating milk

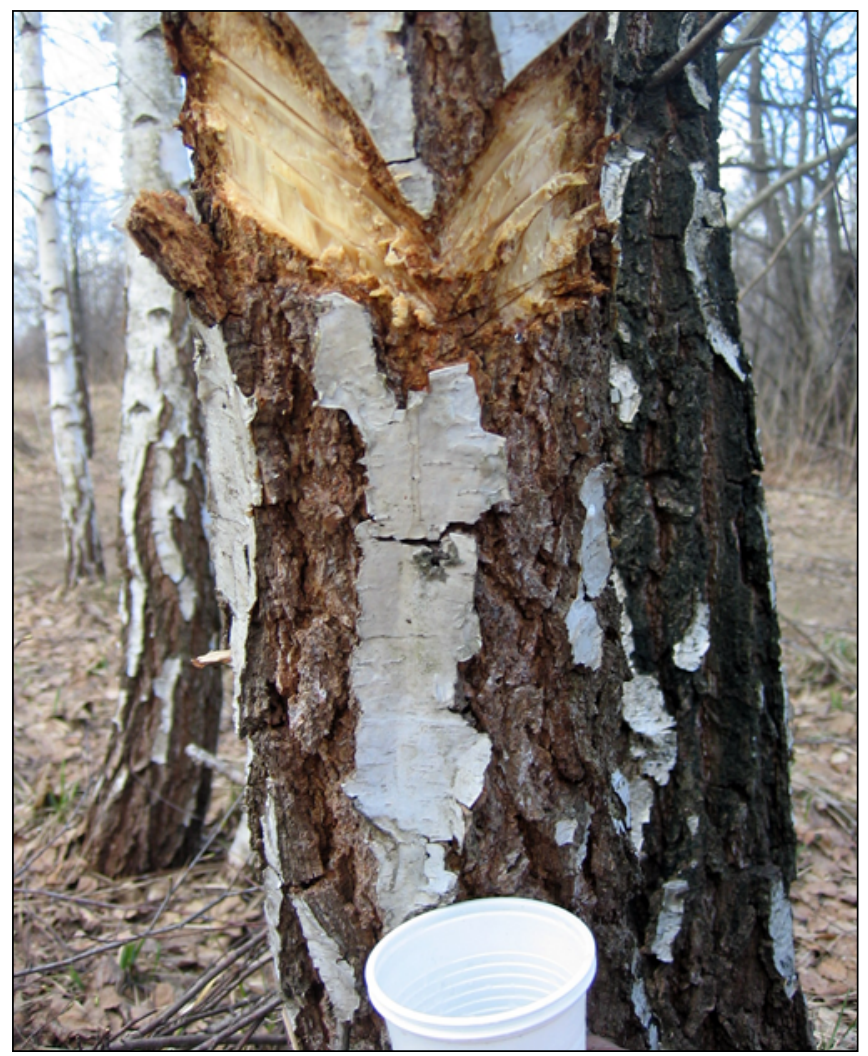

Fig. 8 Collecting birch sap in a Romanian forest. Photograph: Nora Papp. 


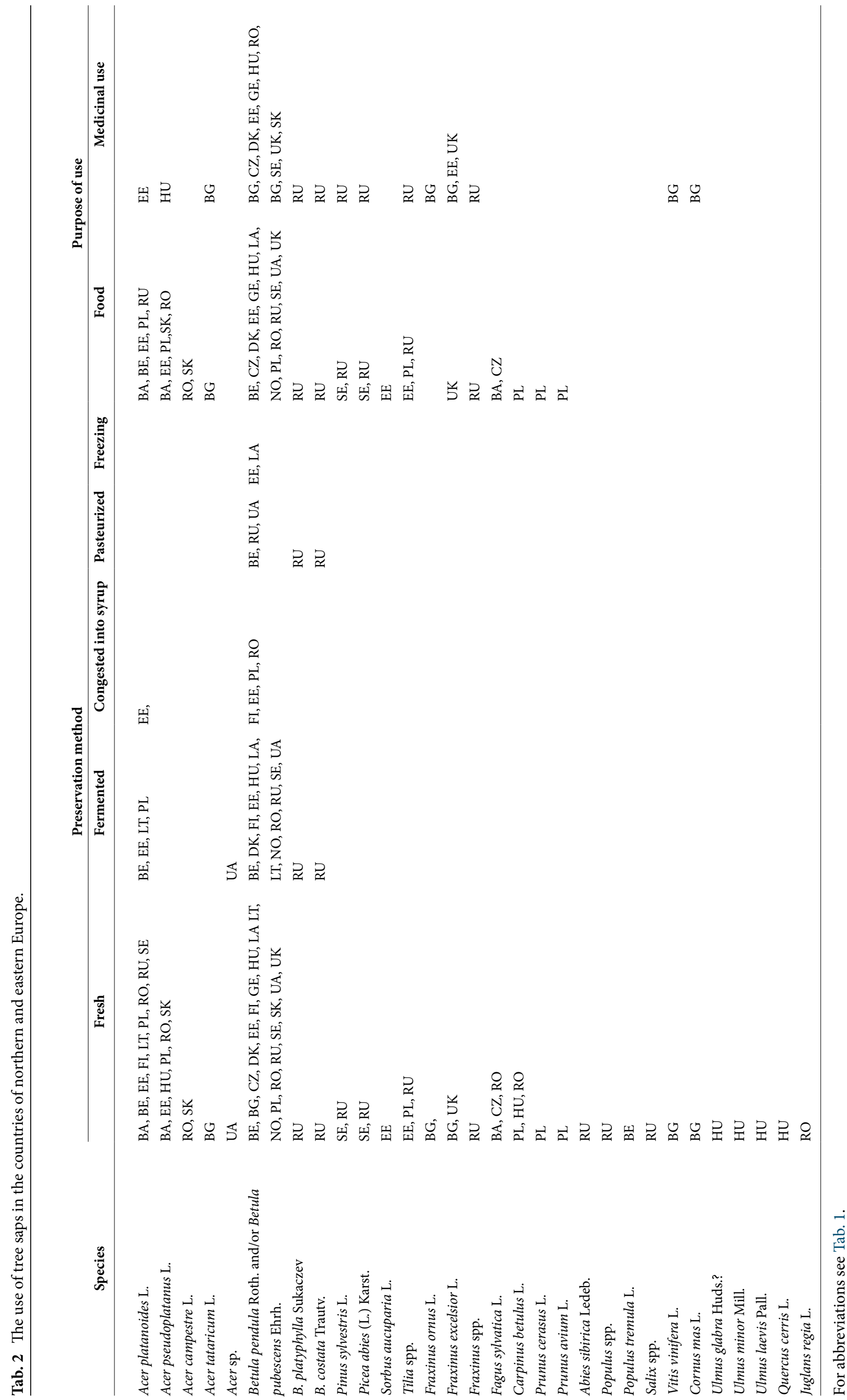


when making cheese [162]. Herdsmen preferred drinking sap to water, because sap helps with the digestion of heavy food. In veterinary practice it was used against bloating, dysentery and as a diuretic [160]. Sap of A. pseudoplatanus was taken against coughs [153].

Tapping of Q. cerris was last reported in Hungary in the 1960s [154], although it was forbidden by law then. Today, tree sap collecting has become extinct.

\section{Romania}

Both maple and birch sap were occasionally used in Romania, both by Romanians and Transylvanian Hungarians [163-165]. Sap from A. pseudoplatanus and A. platanoides have been tapped and used fresh by children $[163,164]$, as well as $A$. campestre [164]. In Transylvania the sap from $B$. pendula was known as "virics" ("birch water"). It was extracted by various methods, according to the reports from the 18th to the 20th century. The tree-trunk was slit with an axe (Fig. 8) or a knife at various heights and directions, or drilled to make a hole $[146,166,167]$. Generally, a funnel made from birch bark, or a stem of reed Phragmites australis (Cav.) Steud., elder Sambucus nigra L. or hemlock, Conium maculatum L. collected in the previous year [168], was applied to the section or a hole, leaking the sap into a piece of pottery $[164,169]$. Birch sap was given to weak children to strengthen them [163].

When local folk medicine was still practiced in Transylvania, birch sap was sold in barrels in the local town markets, and stored in cellars before use [168]. Virics was used against jaundice and to remove kidney stones, and for coagulating milk when making cheese $[162,170]$. It has been mentioned as a treatment against cold [164,171], scab, eye disorders and as a diuretic $[163,172,173]$, but also against constipation, goitre, headache and pneumonia. Blended with oil it could be used to heal wounds [168]. Among the external applications, the washing of moles and sunspots, the use as hair colouring with sugar [168], and as a hair conditioner have been documented in the country [174]. Moreover, birch sap has been consumed in spring as a thirst-quenching drink $[164,175]$, and as fermented or boiled for making wine, beer, syrup or vinegar [146,176]. These products were made in special buildings known as "birch-water houses" among the Hungarian-speaking Szekély [3]. The utilisation of birch sap is a disappearing practice in contemporary Romania.

Tapping of hornbeam (C. betulus), beech (F. sylvatica) and walnut (Juglans regia L.) is reported from Transsylvania [164]. Also grapevine (Vitis vinifera) sap is used among Venetian diaspora and wider to treat eye inflammations [177].

\section{Discussion and conclusions}

The presented data shows that tree saps have been harvested in many European countries (Tab. 2). It can be assumed that tree saps were most widely used where there were extensive birch or maple stands, as these two genera produce the largest amount of sap.

Two main uses of tree saps apply to most countries. The first one is nutritional. Their sugar content made tree saps a valuable nutritional resource. This was utilized mainly in the form of fresh and fermented beverages, as the extraction of condensed sugar syrup from European tree species requires more energy than in the case of the North American Acer saccharum. The second was medicinal use (Tab. 3). Tree saps were believed to contain some vital substances, hence, for example their use to restore the growth of hair.

Russia, Ukraine, Belarus, Estonia, Latvia and Lithuania are the only countries where the use of tree sap (especially birch sap) has remained an important activity. This is due to the

Tab. 3 Medical/cosmetic applications of tree saps.

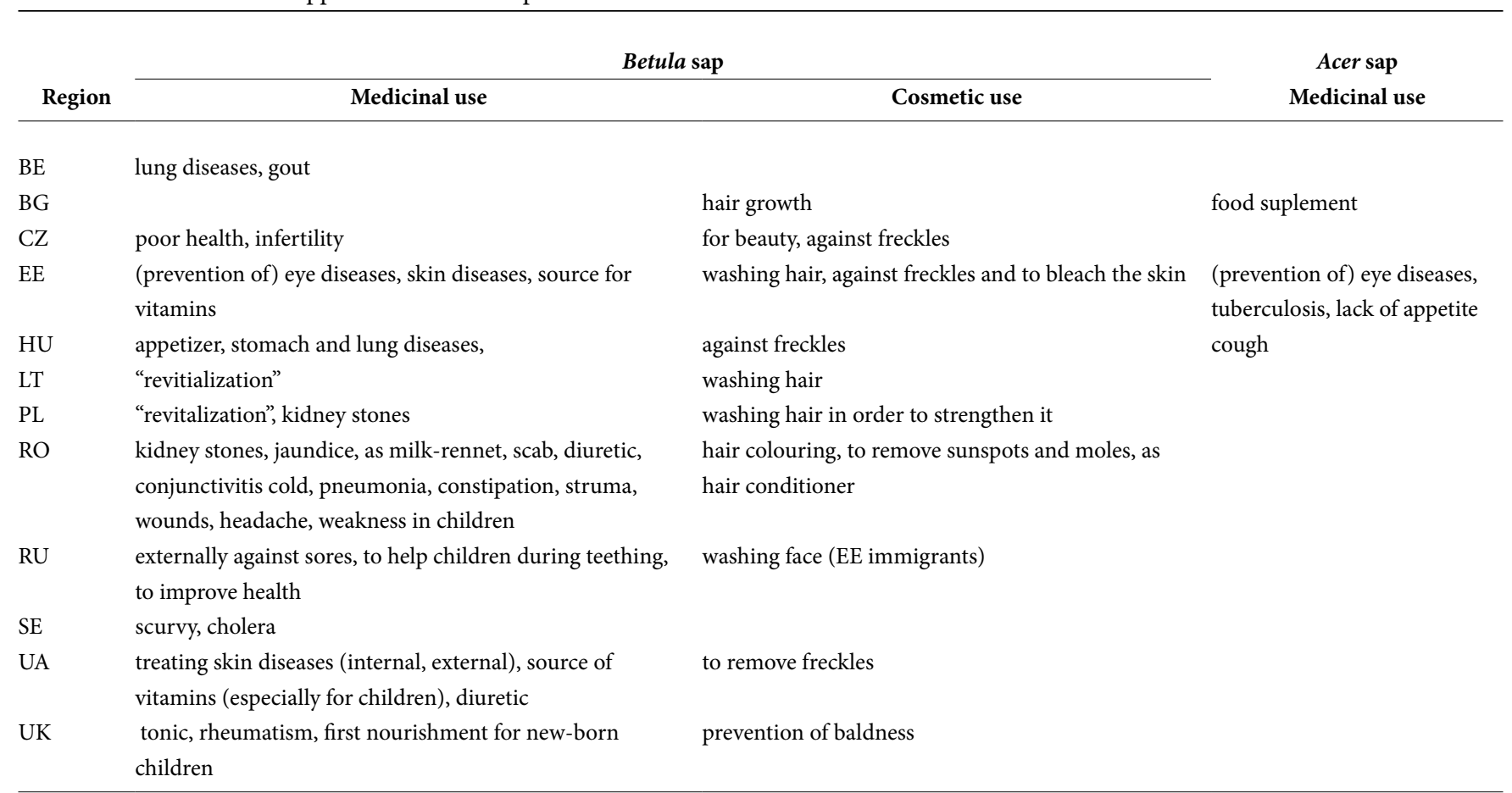

For abbreviations see Tab. 1. 
existence of large birch forests, low population density and the incorporation of sap production into the former Soviet economic system.

There is also a large body of evidence for the extensive use of tree saps from Scandinavia, Hungary, Poland and other central European countries (e.g. Slovakia and Romania) but it has mainly a historical character, as the extraction of tree sap in these countries is nowadays viewed as a curiosity carried out only by some individuals. However, in some regions tree sap is slowly regaining its popularity in urban settings through niche trading (delicatessen, health food shops, etc.).

\section{Remarks}

Authors contribution (author initials): initiation and assembling of the article (RS, $€ €, I S)$, "Introduction" (IS, RS, $€ €, O Z$ ), tables (RS, AN, NP, ŁŁ, IS), Scandinavia (IS), Estonia (RK, RS, IS), Latvia (IS, RK), Lithuania (DS, IS), British Isles (IS, RS), Poland and Slovakia (ŁŁ), Czech Republic (IS, VK), Belarus (ŁŁ, IS, RS, RK, VK), Russia (OZ, IS, RK, VK), Ukraine (ŁŁ, IK-D), Romania (NP, ŁŁ, AD), Bosnia (IS, ŁŁ), Slovenia (IS), Hungary (AD), Bulgaria (AN).

\section{References}

1. Berg G. Nordskandinaviskt - nordeuropeiskt. Rig. 1933;16:118-139.

2. Berg G. Att tappa björklake. Gastronomisk kalender 1968. 1969:35-57.

3. Gunda B. Nyírvíz (szócikk). In: Magyar Néprajzi Lexikon (N-Szé). Budapest: Akadémiai Kiadó; 1987. p. 62. (vol 4).

4. Haberland A. Die volkstümliche Kultur Europas. In: Buschan G, editor. Illustrierte völkerkunde. Stuttgart: Strecker und Schröder; 1926. (vol 2).

5. Manninen I. Überreste der Sammlerstufe und die Notnahrung aus dem Pflanzenreich bei den nordeurasischen, vorzugsweise den finnischen Völkern. Eurasia Septentrionalis Antiqua. 1931;6:30-48.

6. Rein K. Meditsiinitopograafia Tartu linna kohta aastast 1631. Mäetagused. 2010;45:105-144.

7. Eagleson J, Hasner R. The maple syrup book. Boston MA: Boston Mills Press; 2006.

8. Henning DD. Maple sugaring. History of a folk technology. Keystone Folkl Q. 1966;11:239-274.

9. Munson PJ. Still more on the antiquity of maple sugar and syrup in aboriginal Eastern North America. J Ethnobiol. 1989;9:159-170.

10. Eidlitz K. Food and emergency food in the circumpolar area. Uppsala: Almqvist and Wiksells; 1969. (Studia Ethnographica Upsaliensia; vol 32).

11. Ollikainen T. Belarus forestry strategic plan and the non-wood forest products. In: Lund HG, Pajari B, Korhonen M, editors. Sustainable development of non-wood goods and benefits from boreal and cold temperate forests: proceedings of the international workshop. Joensuu: European Forest Institute; 1998. p. 159-162.

12. Rebane H. Voolab kasemahl. Eesti Loodus. 1977;4:223-228.

13. Silm E. Kasemahla varumise kogemustest Tartu Metsamajandis [Master thesis]. Tartu: Eesti Põllumajanduse Akadeemia; 1977.

14. Steinmetz EF. Betula species. Pharm Biol. 1963;3:334-351.

15. Helfferich D. Birch: white gold in the boreal forest. Agroborealis. 2003;35:4-12.

16. Kallio H. Towards Nordic co-operation in aroma research: are we on the right track. In: Plant based specialty products and biopolymers: Tema Nord 1997:606. København: Nordic Council of Ministers; 1997. p. $140-146$.

17. Kallio H, Lahdenoja ML, Penttinen R. Electrophoretic profiles of birch sap proteins of Betula pubescens, B. pendula and B. pendula forma carelica in Finland with reference to overall composition of sap. In: The 1st International Symposium on Sap Utilization (ISSU) in Bifuka '95, Bifuka, Hokkaido, Japan, April 10-12; 1995. Hokkaido: Hokkaido University Press; 1995. p. 13-21.

18. Kallio H. Aroma of birch syrup. J Agric Food Chem. 1989;37(5):13671371. http://dx.doi.org/10.1021/jf00089a035

19. Ahtonen S, Kallio H. Identification and seasonal variations of amino acids in birch sap used for syrup production. Food Chem. 1989;33(2):125-132. http://dx.doi.org/10.1016/0308-8146(89)90115-5

20. Kallio H, Teerinen T, Ahtonen S, Suihko M, Linko RR. Composition and properties of birch syrup (Betula pubescens). J Agric Food Chem. 1989;37(1):51-54. http://dx.doi.org/10.1021/jf00085a012

21. Macku C, Kallii H, Takeoka G, Flath R. Aspects on the use of headspace GC on-column injections in flavor research. J Chromatogr Sci. 1998;26(11):557-560. http://dx.doi.org/10.1093/chromsci/26.11.557

22. Kallio H. Comparison and characteristics of aroma compounds from maple and birch syrups. In: Charalambous G, editor. Proceedings of the 5th International Flavor Conference, Porto Carras, Greece, July 1-3, 1987. Amsterdam: Elsevier; 1988. p. 241-248.

23. Kallio $\mathrm{H}$, Ahtonen $\mathrm{S}$. Seasonal variations of the acids in birch sap. Food Chem. 1987;25(4):285-292. http://dx.doi. org/10.1016/0308-8146(87)90015-X

24. Kallio H, Rine S, Pangborn RM, Jennings W. Effect of heating on the headspace volatiles of Finnish birch syrup. Food Chem. 1987;24(4):287-299. http://dx.doi.org/10.1016/0308-8146(87)90104-X

25. Kallio H, Ahtonen S. Seasonal variations of the sugars in birch sap. Food Chem. 1987;25(4):293-304. http://dx.doi. org/10.1016/0308-8146(87)90016-1

26. Kallio H, Karppinen T, Holmbom B. Concentration of birch sap by reverse osmosis. J Food Sci. 1985;50(5):1330-1332. http://dx.doi. org/10.1111/j.1365-2621.1985.tb10470.x

27. Meeuse BJD. Observations on the enzymatic action of maple and birch saps. New Phytol. 1949;48(2):125-145. http://dx.doi. org/10.1111/j.1469-8137.1949.tb05115.x

28. Balitsky KP, Vorontsova AL. Lekarstvennye rasteniya $v$ terapii rakovykh opukholey. 3rd ed. Rostov-na-Donu: Rostovskoe knizhnoe izdatel'stvo; 1980.

29. Deryabina FI. Materialy po izucheniyu narodnoy meditsiny KomiPermyatskogo natsional'nogo okruga. 3rd ed. Perm: Perm Farm Inst; 1969.

30. Krylov GV, Stepanov EV. Zelenaya apteka Kuzbassa. 2nd ed. Kemerovo: Kemerovskoe knizhnoe izdatel'stvo; 1979.

31. Kucherov EV, Lazareva DN, Desyatkin VK. Dikorastushchie lekarstvennye rasteniya Bashkirii. Ufa: Bashkirskoe; 1973.

32. Turova AD. Lekarstvennye rasteniya SSSR i ikh primenenie. 2nd ed. Moscow: Meditsyna; 1974.

33. Fedorov A, editor. Rastitel'nye resursy SSSR Tsvetkovye rasteniya ikh khimicheskiy sostav ispol'zovanie. Semeystva Magnoliaceae-Limoniaceae. Leningrad: Nauka; 1984.

34. Beskrovny AM, Khuden'ky YK, Bobylev ET, Baranenko SE. Bioneorganicheskie kompleksy "Biomos" kak perspektivnyy produkt luchevoy obrabotki soka listvennykh porod. In: Proceedings of the All-Union Conference "Podsochka i pererabotka soka listvennykh porod". Lvov: Lvovskoe knizhnoe izdatel'stvo; 1977. p. 56-57.

35. Orlov II. Berezovyy i klenovyy soki dobycha i ispol'zovanie. Moscow: Lesnaya promyshlennost; 1974.

36. Evseeva NV. Bereza tvorit chudesa lechenie dyogtem pochkami list'yami i sokom-. St. Petersburg: Nevskiy prospekt; 2005.

37. Pieroni A. Medicinal plants and food medicines in the folk traditions of the upper Lucca Province, Italy. J Ethnopharmacol. 2000;70(3):235-273. http://dx.doi.org/10.1016/S0378-8741(99)00207-X

38. Pieroni A, Gray C. Herbal and food folk medicines of the Russlanddeutschen living in Künzelsau/Taläcker, South-Western Germany. Phytother Res. 2008;22(7):889-901. http://dx.doi.org/10.1002/ptr.2410 
39. Blanco E, Macia MJ, Morales R. Medicinal and veterinary plants of El Caurel (Galicia, northwest Spain). J Ethnopharmacol. 1999;65(2):113-124. http://dx.doi.org/10.1016/S0378-8741(98)00178-0

40. Moriyama M, Naru E, Misaki Y, Hayashi A. Effect of birch (Betula platyphylla Sukatchev var. japonica Hara) sap on cultured human epidermal keratinocyte differentiation. Int J Cosmet Sci. 2009;31(2):159-160. http:// dx.doi.org/10.1111/j.1468-2494.2008.00466_3.x

41. Paulli S. Flora Danica. Det er: Dansk Urtebog. København: M. Martzan; 1648.

42. Brøndegaard VJ. Folk og flora: Dansk etnobotanik. København: Rosenkilde og Bagger; 1978-1979. (vol 1-2).

43. Lange J. Løvtræer. In: Granlund J, editor. Kulturhistoriskt lexikon för nordisk medeltid. Malmö: Allhem; 1966. p. 185-198. (vol 11).

44. Lange A, Seeberg C. Nogle sønderjydske Planter, deres Navne og Stilling i Folkloren. Tønder: H. Chr. Bakkes Boghandel; 1929.

45. Claussøn Friis P. Samlede Skrifter. Kristiania: A. W. Brøgger; 1881.

46. Høeg OA. Planter og tradisjon. Oslo: Universitetsforlaget; 1964.

47. Levander L. Livet i en Älvdalsby före 1870-talet. Stockholm: Norstedt; 1914.

48. Levander L. Övre Dalarnas bondekultur under 1800-talets förra hälft. 3, Hem och hemarbete. Uppsala: Jonsson \& Winter; 1947.

49. Svanberg I, Tunón H. Bark, näver och sav. In: Pettersson B, Svanberg I, Tunón H, editors. Människan och naturen: etnobiologi i Sverige. Stockholm: Wahlström \& Widstrand; 2001. p. 79-84. (vol 1).

50. Krok S. Urshults pastorats inbyggares seder: tal hållet ... inför Småländska nationen i Uppsala den 11 december 1749. Stockholm: Björck \& Börjesson; 1922.

51. Svanberg I. Folklig botanik. Stockholm: Dialogos; 2011.

52. Fischerström J. Nya Swenska economiska dictionnairen. Eller Försök til et allmänt och fullständigt lexicon i Swenska hushållningen och naturläran. Stockholm: Carl Stolpe; 1780. (vol 2).

53. Hildebrand S. En holländsk beskicknings resor i Ryssland, Finland och Sverige 1615-1616: trenne reseberättelser, från de tryckta och handskrivna holländska originalen. Stockholm: Norstedt \& Söner; 1917.

54. Säve PA. Skogens sagor eller växtligheten på Gotland, jemte spridda drag ur öns odlingssaga och folklifvet derstädes. Stockholm: I. Haeggström; 1877.

55. Drake SAMC. Västerbottenslapparna under förra hälften av 1800-talet. Uppsala: Almqvist \& Wiksells; 1918.

56. Warg C. Hjelpreda i hushållningen för unga fruentimber. Stockholm: Lor. L Grefing; 1755.

57. Synnerberg LN. Svenskt waru-lexicon uti sammandrag ur de mest bekanta författares arbeten, rörande handeln. Göteborg: S Norberg; 1815.

58. Valleria C. Christina Vallerias hushållsbok från tiden omkr. år 1700. Uppsala: Nordblads; 1931.

59. Nylander M. Handbok wid den nu brukliga finare matlagningen. Stockholm: Samel Rumstedt; 1828.

60. Cronquist AW. Illustrerad ordbok öfver näringsämnen och handelsartiklar. Stockholm: Hæggström; 1879.

61. Räsänen M. Charakteristika der finnischen Getreidegetränketradition. In: Ethnologische Nahrungsforschung: Vorträge der zweiten Internationalen Symposiums für ethnologische Nahrungsforschung : Helsinki August 1973. Helsinki: Suomen Muinaismuistoyhdistys; 1975. p. 206-211. (Kansatieteellinen arkisto; vol 6).

62. Vuorela T. Suomalainen kansankulttuuri. Porvoo-Helsinki: Werner Söderström; 1975.

63. Vuorela T. Suomensukuiset kansat. Helsinki: Suomalaisen Kirjallisuuden Seura; 1960.

64. Itkonen TI. Lappalaisten ruokatalous. Helsinki: Suomalais-ugrilainen seura; 1921.

65. Lehtonen JUE. Mahlan käyttö karjan ravintona. Kotiseutu. 1970;2-3:40-42.

66. Kalm P. Oeconomisk Beskrifning öfwer Björkens Egenskaper och Nytta i den Allmänna Hushållningen. (Disp., 33 sid., 4:o). Åbo: J Merckell; 1759.
67. Inkilä AT. Mahlavarvu aika ja "onneton Ollin päiva”. Kotiseutu. 1939;1:42-45.

68. Talve I. Finnish folk culture. Helsinki: Finnish Literature Society; 1997.

69. Rasanen M. Savokarjalainen ateria: Savokarjalainen ruoka ja ruokakulttuuri muuttuvassa maailmassa. Helsinki: Otava; 1980.

70. Göseken H. Manuductio ad linguam Oesthonicam, Anführung zur öhstnischen Sprache. Tallinn: Adolph Simon; 1660.

71. Velten C. Adolf Nicklassen vom Steinkallenfels Reisse in Schweden und Liefflandt 1615. Bad Kreuznach: Selbstverlag; 1958.

72. Hupel AW. Topographische Nachrichten von Lief- und Ehstland: Nebst vollständigen Register über alle drey Bände. Riga: J. F. Hartknoch; 1777.

73. Söderbäck P. Rågöborna. Stockholm: Norstedt; 1940. (Nordiska Museets Handlingar; vol 13).

74. Danell G. Ordbok över Nuckömålet. Uppsala: Almqvist \& Wiksells; 1951. (Estlandssvenskarnas folkliga kultur; vol 2).

75. Wiedemann FJ. Estnisch-deutsches Wörterbuch. St. Petersburg: Buchdruckerei der Kaiserlichen Akademie der Wissenschaften; 1869.

76. Saareste A. Eesti keele mõisteline sõnaraamat. Stockholm: Vaba esti; 1959. (vol 2).

77. Ostrat A. Andmeid mahla kogumise ja selles leiduva suhkru kasutamise võimalustest. Eesti mets. 1943;5:120-123.

78. Kalle R, Sõukand R. Ajalooline ülevaade eestlaste looduslikest toidu-ja ravimtaimedest. In: Kusmin T, Meikar T, editors. Metsa kõrvalkasutus Eestis. Tartu: Eesti Metsaselts; 2011. p. 29-44. (Akadeemilise Metsaseltsi Toimetised; vol 25).

79. Silm E, Linnus A. Kasemahla varumisest Tartu metsamajandis. Mets Puit Paber. 1980;5:13-14.

80. Raudsepp P. 65 tonni kasemahla. Punalipp. 1976;57:1.

81. Relve H. Metsaomanik müüb kasemahla Itaaliasse. Eesti Mets. 2005;2:15-17.

82. Moora A. Kuidas vanasti kasemahla võeti. Eesti Loodus. 1982;4:241-244.

83. Moora A. Mida vanasti kasemahlast tehti. Eesti Loodus. 1982;5:298-300.

84. Spuhl-Rotalia JG. Kodumaa marjad. Viljandi: A Peet; 1898.

85. Tonka K. Heinaajajook võtab janu ja annab tervist. Järva Teataja. 2010:45.

86. Sõukand R, Kalle R. HERBA: historistlik Eesti rahvameditsiini botaaniline andmebaas [Internet]. 2008 [cited 2012 Jul 15]; Available from: http:// herba.folklore.ee

87. Loorits O. Endis-eesti elu-olu: Lugemispalu metsaelust ja jahindusest. 2nd ed. Tartu: Eesti Kirjandusmuuseum; 2004. (Eesti Rahvaluule Arhiivi Toimetused; vol 21).

88. Ritter von Miklosich F. Die slavischen Monatsnamen. Wien: K. Gerold's Sohn; 1867.

89. Bielenstein AJG. Die Holzbauten u. Holzgeräte der Letten. Ein Beitrag zur Ethnographie, Kulturgeschichte und Archäologie der Völker Rußlands im Westgebiet. Petrograd: Tip. Rossī̌skoĭ Akademiii Nauk; 1918. (vol 2).

90. Kettunen L. Livisches Wörterbuch. Mit grammatischer Einleitung. Helsinki: Suomalais-ugrilainen seura; 1938. (Lexica Societatis Fenno-Ugricae; vol 5).

91. Rothbergs U. Forests and forestry in Latvia. In: Paulenka J, Paule L, editors. Conservation of forests in Central Europe: Proceedings of the WWF workshop held in Zvolen, July 7-9, 1994. Zvolen: Arbora; 1994. p. 79-87.

92. Cappeller C, Charpentier J. Hur de gamla litauerna levde. Le Monde Oriental. 1906;1:101-133.

93. Bohdanowicz J. Pożywienie. Zbieractwo - pożywienie głodowe. In: Bohdanowicz J, editor. Komentarze do Polskiego Atlasu Etnograficznego: pożywienie i sprzęty z nim związane. Wrocław: Polish Ethnological Society; 1996. p. 10-21.

94. Milius V. Dubičiai. Vilnius: Mintis; 1989.

95. Kalašaitytė L. Liaudies medicinos priemonès. In: Vèlius N, Jonaityte A, Merkys V, Milius V, Račkauskas K, Vidugiris A, editors. Gervěčiai. Vilnius: Mintis; 1989. p. 204-219.

96. Edlin HL. Woodland crafts in Britain: an account of the traditional uses of trees and timbers in the British countryside. London: B. T. Batsford; 1949. 
97. Milliken W, Bridgewater S. Flora Celtica: plants and people in Scotland. Edinburgh: Birlinn; 2004.

98. Hatfield G. Encyclopedia of folk medicine: old world and new world traditions. Oxford: ABC-CLIO; 2003.

99. Allen DE, Hatfield G. Medicinal plants in folk tradition. An ethnobotany of Britain \& Ireland. Portland OR: Timber Press; 2004.

100.von Reinsberg-Düringsfeld O. Fest-Kalender aus Böhmen: ein Beitrag zur Kenntniss des Volkslebens und Volksglaubens in Böhmen. Prague: J. L. Kober; 1862.

101. Vinogradova LN, Usacheva VV. Bereza. In: Tolstoy NI, editor. Slavyanskie drevnosti. Etnolingvisticheskiy slovar'. Moscow: Institut Slavyanovedeniya RAN; 1995. p. 156-160. (vol 1).

102. Grohmann JV. Povery a obyceje v Cechách a na Morave. Prague: Plot; 2010.

103. Marzell H. Volksbotanik. Die Pflanze im deutschen Brauchtum. Berlin: Enckehaus; 1935.

104. Moszyński K. Kultura ludowa Słowian: kultura materialna. Cracow: Polish Academy of Arts and Sciences; 1929.

105. Jankowska B. Ściąganie na wiosnę pitnych soków drzew. In: Gajek J, editor. Polski atlas etnograficzny (map No. 311). Warsaw: Polish Scientific Publishers PWN; 1981. (vol 6).

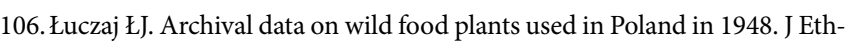
nobiol Ethnomed. 2008;4(1):4. http://dx.doi.org/10.1186/1746-4269-4-4

107. Łuczaj $€$. Wild food plants used in Poland from the mid-19th century to the present. Etnobiologia Polska. 2011;1:57-125.

108. Łuczaj $€$, Szymański WM. Wild vascular plants gathered for consumption in the Polish countryside: a review. J Ethnobiol Ethnomed. 2007;3(1):17. http://dx.doi.org/10.1186/1746-4269-3-17

109. Dekowski JP. Rośliny dziko rosnące w tradycyjnym pożywieniu chłopów kozienickich. In: Kowalska-Lewicka A, editor. Pożywienie ludności wiejskiej. Cracow: Ethnographic Museum; 1973. p. 247-256.

110. Chętnik A. Pożywienie Kurpiów. Jadło i napoje zwykłe, obrzędowe i głodowe. Prace Komisji Etnograficznej. 1936;16:1-134.

111. Holuby JL. Die gewöhnlichsten wildwachsenden Genusspflanzen des Trencsiner Comitates. Verhandlungen des Vereins für Natur-und Heilkunde zu Pressburg. Neue Folge. 1891;7:91-105.

112. Holuby JL. Aus der Botanik slowakischer Kinder des Trentschiner Komitates in Ungarn. Deutsche Botanische Monatsschrift. 1896;19(8-9):126-131.

113. Markus M. Ludova stravá. In: Mjartan J, editor. Banícka dedina Žakarovce. Bratislava: Vydavatel'stvo Slovenskej Akadémie Vied; 1956. p. 283-324.

114. Stoličná R. Alternative sources of food in Central Europe. In: Lysaght P, editor. Food from nature: attitudes, strategies and culinary practices. Proceedings of the 12th Conference of the International Commission for Ethnological Food Research, Umeå and Frostviken, Sweden, 8-14 June, 1998. Uppsala: The Royal Gustavus Adolphus Academy for Swedish Folk Culture folkkultur; 2000. p. 195-203. (Acta Academiae Regiae Gustavi Adolphi; vol 71).

115. Kruk I, Shved I. Byaroza. In: Vladozina T, Sanjko S, editors. Mifalogya belarusa Entsykl slojn. Minsk: Belarus; 2001. p. 58-59.

116. Rebane H. Kask - meie kodumaa kauneim puu. Eesti Loodus. 1970;10:582-588.

117.Eilart J. Mahlajooks - elusa looduse kevade algus. Eesti Loodus. 1959;2:122-123.

118. Borisovskiy konservnyy zavod ostavil zayavki v leskhozakh na zakupku tystonn berezovogo soka [Internet]. Adzinstva. 2012 [cited 2012 Jun 26]; Available from: http://www.adzinstva.by/?p=57912

119. Collecting birch sap [Internet]. The State Inspectorate on Wildlife Protection under the President of the Republic of Belarus. 2012 [cited 2012 Jun 26]; Available from: http://gosinspekciya.gov.by/en/news/ inspectorate/01april2010birch.html

120. Nikitinsky YY. Surrogaty i neobychnye v Rossii istochniki pishchevykh sredstv rastitel'nogo i zhivotnogo proiskhozhdeniya. Moscow: Gosizdat; 1921.
121. Koldaev VN. Prizhiznennoe ispol'zovanie bereznyakov. Lesn kho-zvo. 1971;4:71-76.

122. Zelenin DK. Russische (Ostslavische) Volkskunde. Berlin: W. de Gruyter; 1927.

123. Toren MD. Russkaya narodnaya meditsina i psikhoterapiya. St. Petersburg: Litera; 1996.

124. Öpik E. Vadjalastest ja isuritest XVIII sajandi lõpul: etnograafilisi ja lingvistilisi materjale F. Tumanski Peterburi kubermangu kirjelduses. Tallinn: Valgus; 1970.

125. Paasonen H. Mordwinisches Wörterbuch. Helsinki: Suomalais-ugrilainen seura; 1992. (Lexica Societatis Fenno-ugricae; vol 23).

126. Jochelson W. The Yukaghir and the Yukaghirized Tungus. Leiden: E. J. Brill; 1910. (vol 1).

127. Georgi JG. Beschreibung aller Nationen des russischen Reichs: ihrer Lebensart, Religion, Gebräuche, Wohnungen, Kleidungen und übrigen Merkwürdigkeiten. St. Petersburg: C. W. Müller; 1776. (vol 2).

128. Steller GW. Beschreibung von dem lande Kamtschatka, dessen einwohnern, deren sitten, nahmen, lebensart und verschiedenen gewohnheiten. Frankfurt-Leipzig: J. G. Fleischer; 1774.

129. Roshchin V, Sultanov V. Complex utilization of tree biomass through harvest of birch sap and coniferous cell sap. In: Proceedings of the 1st International Symposium on Sap Utilization (ISSU) in Bifuka '95, Bifuka, Hokkaido, Japan, April 10-12, 1995. Hokkaido: Hokkaido University Press; 1995. p. 111-115.

130. Zyryanova OA, Terazawa M, Koike T, Zyryanov VI. White birch trees as resource species of Russia: their distribution, ecophysiological features, multiple utilization. Eurasian J For Res. 2010;13:25-40.

131. Izmodenov AG. Siledia. Nachalo teorii. Soki i yagody dikorossov. Khabarovsk: Khabarovskoe knizhnoe izdatel'stvo; 2001.

132. Tolstykh VI, Taghiltsev YG, Kolesnikova RD, Lodygin BS. Soki dal'nevostochnykh berez. In: Proceedings of the 2nd International Conference "Forest bioactive resources", Khabarovsk, September 21-23, 2004. Khabarovsk: Khabarovskoe knizhnoe izdatelstvo; 2004. p. 203-206.

133. Khlynov VI. Ob usloviyakh i merakh po rasshireniyu zagotovki pererabotki i prodazhi prirodnykh produktov v Khabarovskom krae. In: Proceedings of the 2nd International Conference "Forest bioactive resources", Khabarovsk, September 21-23, 2004. Khabarovsk: Khabarovskoe knizhnoe izdatelstvo; 2004. p. 10-17.

134. Taghiltsev YG, Kolesnikova RD. Rasshirenie pishchevykh i tekhnicheskikh produktov i razvitie tekhnologiy proizvodstva bioproduktov. In: Gassinskiy opytnyy les. Problemy mnogotselevogo ispol'zovaniya. Khabarovsk: Khabarovskoe knizhnoe izdatelstvo; 1990. p. 91-98.

135. Khramov AA. Tapping of phloem sap in woody plants. In: Proceedings of the 1st International Symposium on Sap Utilization (ISSU) in Bifuka '95, Bifuka, Hokkaido, Japan, April 10-12, 1995. Hokkaido: Hokkaido University Press; 1995. p. 117-122.

136. Łuczaj Ł. Brzozowy sok, "czeremsza" i zielony barszcz - ankieta etnobotaniczna wśród botaników ukraińskich. Birch sap, ramsons and green borsch - an ethnobotanical survey among Ukrainian botanists. Etnobiologia Polska. 2012;2:15-22.

137. Harchenko MS, Syla VI, Volodars'kyj LJ. Likarski roslyny i i'h zastosuvannja v narodnij medycyni. Kiev: Zdorov'ja; 1971.

138. Shevchuk V. Zelenyj dyvosvit Podillja. Rozpovidi ta porady travoznaja. Vinnycja: Derzhavna kartografichna fabryka; 1997.

139. Redzic SJ. Wild edible plants and their traditional use in the human nutrition in Bosnia-Herzegovina. Ecol Food Nutr. 2006;45(3):189-232. http:// dx.doi.org/10.1080/03670240600648963

140. Valvasor JV. Die Ehre dess Hertzogthums Crain: das ist, Wahre, gründliche, und recht eigendliche Belegen- und Beschaffenheit dieses ... RömischKeyserlichen herrlichen Erblandes. Laybach: Wolfgang Moritz Endter; 1689.

141. Suhadolnik S. O brezovi vodi na Notranjskem. Slovenski etnograf. 1962;15:106. 
142. Grafenauer I. Brezen in brezova voda. Slovenski etnograf. 1962;15:101-106. 143. Stoyanov N. Nashite lekarstveni rasteniya. Sofia: Nauka i Izkustvo; 1972. (vol 1).

144. Georgiev M. Encyclopedia Bulgarian folk medicine. Sofia: Petar Beron; 1999.

145. Nikolov SD. Specilizirana enciklopediia na lechebnite rasteniya v Bulgariya. Sofia: Knigoizdatelska kushta Trud; 2006.

146. Kiss L. A nyírvíz. A Földgömb. 1930;1:1-6.

147. Ecsedi I. A debreceni és tiszántúli magyar ember táplálkozása. Debrecen: A Debreceni Déri Múzeum Évkönyve; 1934.

148. C. Schwalm E. Gyüjtögetés, mint nyersanyag-kiegészítő. In: Bakó F, editor. Palócok III. Eger: Heves Megyei Múzeumok Igazgatósága; 1989. p. 417-423.

149. Bödei J. Adatok Zalabaksa gyüjtögető gazdálkodásához. Néprajzi Értesítő. 1943;2:69-96.

150.Fehér J. Adatok Bernecebaráti gyűjtögető és zsákmányoló gazdálkodásához. Néprajzi Értesítő. 1957;2(3-4):267-292.

151. Kardos L. Az Örség népi táplálkozása, Gyüjtögetés. Tanulmányok az Őrség monográfiájához. Budapest: Államtudományi Intézet Táj- és Népkutató Osztálya; 1943.

152. Kóczián G. A hagyományos parasztgazdálkodás termesztett, a gyüjtögető gazdálkodás vad növényfajainak etnobotanikai értékelése. Egyetemi doktori disszertáció. (Ethnobotanical evaluation of the cultivated plants of traditional agriculture, and that of wild plant species of gathering livelihood [PhD thesis]. Mosonmagyaróvár: ATE Mezőgazdasági Kar; 1985.

153. Kóczián G. Etnobotanikai vizsgálatok Répáshután. Répáshuta, egy szlovák falu a Bükkben. A Miskolci Hermann Ottó Múzeum Néprajzi kiadványa. 1984;8:229-256.

154. Paládi-Kovács A. A Barkóság és népe. Miskolc: Herman Ottó Múzeum; 2006.

155. Pethő M. Győr-Moson-Sopron megye XX. századi népi táplálkozásának rövid jellemzése. Arrabona. 36(1-2):137-150.

156. Takáts G. Somogyi pásztorvilág. Kaposvár: Somogy Megyei Múzeumok Igazgatósága; 1986.

157. Ujváry Z. A vadontermő növények szerepe a táplálkozásban az abaújzempléni hegyvidéken. Néprajzi Értesítő. 1957;39:232-234.

158. Varga G. A népi táplálkozás Hajdú-Bihar megyében a XX. század elso felében. Debrecen: Hajdú-Bihar Megyei Múzeumi Igazgatóság; 1993.

159. Gunda. A gyűjtögető gazdálkodás emlékei egy gerecse-hegységi tót faluban. Ethnographia. 1938;49(1-2):213-214.
160. Nagy R. Adatok a Baranyamegyei nagyváty növényekkel kapcsolatos szokásaihoz és néphagyományaihoz. Magyar Népnyelv. 1942;4.

161. Kiss GZ. Zsákmányoló foglalkozások: Halászat gyüjtögetés. In: Kiss GZ, editor. A régi Vajszló: 1244-1849. Pécs: Vajszló Nagyközség Önkormányzata; 1994.

162.Gunda B. Tejoltó növények a Kárpátokban. Ethnographia. 1967;78:161-175.

163. Butură V. Enciclopedie de etnobotanică românească. Bucharest: Editura Științifică și Enciclopedică; 1979.

164. Péntek J, Szabó A. Ember és növényvilág : Kalotaszeg növényzete és népi növényismerete. Bucharest: Kriterion; 1985.

165. Giurescu CC, Farca E. A history of the Romanian forest. Bucharest: Ed. Academiei Republicii Socialiste România; 1980. (Bibliotheca historica Romaniae; vol 63).

166. Gazda K. Gyermekvilág Esztelneken: néprajzi monográfia. Bucharest: Kriterion; 1980.

167. Bartos T. Magyar szótár: egymást magyarázó szavak és fordulatok tára. Budapest: Corvina; 2002.

168. Györffy I. Viricselés a Székelyföldön. Ethnographia. 1937;48(2):205-220.

169. Szebeni G. A csíki juhászat. Ethnographia. 1962;73(1):54-89.

170. Melius P. Herbárium: az fáknak, füveknek nevekről, természetekről és hasznairól. Bucharest: Kriterion; 1978.

171. Tarisznyás M. A gyüjtögető gazdálkodás hagyományai Gyergyóban. In: Kós K, Faragó J, editors. Népismereti dolgozatok. Bucharest: Kriterion; 1978. p. 25-33.

172. Csedő K, editor. Plantele medicinale şi condimentare din județul Harghita. Hargita megye gyógy- és füszernövényei. Târgu Mureş: Tipografia Tirgu Mures; 1980.

173. Rácz G, Rácz-Kotilla E, Laza A. Gyógynövényismeret. Bucharest: Ceres; 1984.

174. Rácz G, Füzi J, editors. Kovászna megye gyógynövényei. Sfântu Gheorghe: Mezőgazdasági, Élelmiszeripari és Vízügyi Igazgatóság; 1973.

175. Rab J, Tankó P, Tankó M. Népi növényismeret Gyimesbükkön. In: János VA, Károly K, József F, editors. Népismereti dolgozatok. Bucharest: Kriterion; 1981.

176. Dieck A. Die Birke (Betula L.) in der Volksmedizin Europas. CurareSonderband. 1985;3:85-94.

177. Pieroni A, Quave CL, Giusti ME, Papp N. “We are Italians!”: the hybrid ethnobotany of a Venetian diaspora in Eastern Romania. Hum Ecol. 2012;40(3):435-451. http://dx.doi.org/10.1007/s10745-012-9493-4 